NBER WORKING PAPER SERIES

THE IMPACT OF HIGH SCHOOL CURRICULUM ON CONFIDENCE, ACADEMIC SUCCESS, AND MENTAL AND PHYSICAL WELL-BEING OF UNIVERSITY STUDENTS

\author{
Han $\mathrm{Yu}$ \\ Naci Mocan \\ Working Paper 24573 \\ http://www.nber.org/papers/w24573 \\ NATIONAL BUREAU OF ECONOMIC RESEARCH \\ 1050 Massachusetts Avenue \\ Cambridge, MA 02138 \\ May 2018
}

The views expressed herein are those of the authors and do not necessarily reflect the views of the National Bureau of Economic Research.

NBER working papers are circulated for discussion and comment purposes. They have not been peer-reviewed or been subject to the review by the NBER Board of Directors that accompanies official NBER publications.

(C) 2018 by Han Yu and Naci Mocan. All rights reserved. Short sections of text, not to exceed two paragraphs, may be quoted without explicit permission provided that full credit, including $($ ) notice, is given to the source. 
The Impact of High School Curriculum on Confidence, Academic Success, and Mental and Physical Well-Being of University Students

Han Yu and Naci Mocan

NBER Working Paper No. 24573

May 2018

JEL No. H0,I1,I20,I23,I3,J38

\begin{abstract}
This paper investigates the causal effect of high school curriculum on various student outcomes including academic performance at the university, happiness, physical and mental health, selfconfidence, confidence in academic ability, and attitudes towards studying and learning. We exploit a curriculum reform in China, the implementation of which started in 2004. The reform covered all provinces and municipal cities, and was rolled out in different years in different provinces. The new curriculum pivoted away from the old lock-step course structure where all students took the same courses and only those subject that were covered in the national university entrance exam were considered important. In contrast, the new curriculum introduced a course credit system, changed textbooks, and provided flexibility in course selection. It also introduced elective courses and made such courses as arts and physical education mandatory, and a graduation requirement. Using survey data on university students and employing a difference-indifference approach, we find that the students who were exposed to the new curriculum in high school have better academic performance in university. They are happier, and their physical and mental well-being is better. These students are more likely to have positive attitudes towards themselves and they are more involved in student clubs. They have more confidence in their academic ability, they have more positive attitudes towards studying, and they have more general self-confidence. These results indicate that the reform had a significant impact on students' academic success and well-being by allowing them to focus on subject matters in which they are interested, and by reducing undue stress of a regimented curriculum.
\end{abstract}

\author{
$\mathrm{Han} \mathrm{Yu}$ \\ Department of Economics \\ Louisiana State University \\ 2416 BEC \\ Baton Rouge, LA 70803 \\ hyu17@1su.edu \\ Naci Mocan \\ Department of Economics \\ Louisiana State University \\ 2439 BEC \\ Baton Rouge, LA 70803-6306 \\ and NBER \\ mocan@1su.edu
}




\section{The Impact of High School Curriculum on Confidence, Academic Success, and Mental and Physical Well-Being of University Students}

\section{Introduction}

It is well documented that educational attainment has a causal impact on wages (see Card 1999, Meghir and Rivkin 2011 for reviews). Primarily motived by the fact that there is substantial heterogeneity in the financial returns to the quantity of schooling between countries as well as within a country, a parallel literature has investigated the extent to which the quality of education impacts student outcomes. Specifically, researchers have analyzed whether the structure of the delivery of education and the course content have an impact on students test scores, on students' propensity to attain more education, and on their future labor market success. ${ }^{1}$

One major branch of this literature examines the extent to which students' future achievements and behaviors are impacted by what is taught in the classroom. For example, Brown et al. (2016) analyzed whether high school courses in financial education, mathematics and economic influence students' financial debt when they become adults. Similarly, Bernheim et al. (2001) investigated the impact of exposure to financial curricula in high school on asset accumulation in adulthood. Altonji (1995), Levine and Zimmerman (1995), and Joensen and Nielsen (2009) are examples of the inquiry into whether taking advanced math and science classes in high school has an impact on labor market outcomes. Other examples of research that investigate the impact of high school curriculum and course content include Rose and Betts (2004) who reported that specific high school math courses influence earnings of students one decade after graduation, and Cole et al. (2016) who showed that state-mandated mathematics courses taken as

\footnotetext{
${ }^{1}$ These analyses include such inquiries as whether the length of the school year and additional instructional time influence student learning, achievement and subsequent earnings (Lavy 2015, Pischke 2007) and whether homework is beneficial to students learning (Eren and Henderson 2008).
} 
part of the high school curriculum lead to more investment income and better credit management in the future.

This literature, briefly summarized above, has two important attributes. First, the overwhelming majority of research employed data from developed countries, particularly the United States. Second, research has focused on outcomes such as students' likelihood of attending college, their choice of college major, or financial decisions and labor market outcomes in the future. $^{2}$ A notable exception is a recent paper by Cantoni et al. (2017) which exploited a curriculum reform in China and analyzed the impact of the reform on students' political attitudes. This Chinese reform, the implementation of which started in 2004, was rolled out through different provinces of China until $2012^{3}$. As we detail in Section II and as described in Cantoni et al. (2017), the reform was a major overhaul of the high school curriculum. The reform changed the textbooks and significantly modified the way in which classes are taught. Teachers underwent training for the new curriculum. A major component of the new curriculum was the introduction of a system that allowed the students to take elective courses in many subjects, which in turn provided flexibility for students to focus on subject matters in which they were interested. The new curriculum also placed emphasis on physical education by making it impossible to replace a physical education class with math or science classes, which had been typical practice under the old curriculum to better prepare the students for the high-stakes university entrance exam. ${ }^{4}$

\footnotetext{
${ }^{2}$ A technical summary of the literature on the impact of high school curriculum on college choice and labor market outcomes is provided by Altonji, Blom and Meghir (2012).

${ }^{3}$ The preparation for the reform started in 1999. This curriculum reform covered the entire basic education system in China. We focus on the high school curriculum in this study. We discuss the details of the reform in section II.

${ }^{4}$ As described in section II, the new curriculum mandates the students to take 198 45-minute physical education classes over three years in high school to be able to graduate.
} 
Cantoni et al. (2017) focus on the impact of high school politics classes of this new curriculum. The authors argue that the politics classes of the new curriculum were designed for "moral and ideological education" (Cantoni el al. p. 346), and they show that the contents of the new politics classes matched the government's objective of shaping students' political and social beliefs. The authors find that students who were exposed to the new curriculum have more positive views on China's governance and that they are more skeptical of free markets. This result implies that classroom instruction and course content can be a vehicle through which students can be indoctrinated, and through which their political views can be shaped.

In this paper we use the same Chinese high school curriculum reform to estimate the causal effect of the reform on students' educational success in university, on their mental health as well as physical well-being. We also analyze the extent to which the reform had an impact on students' happiness, self-confidence, and confidence in their academic ability.

The hypothesis that students' physical well-being (measured by the body mass index), and their mental health could be impacted by the curriculum reform is motivated directly by the goals, the structure and the implementation of the reform. For example, the reform placed emphasis on physical education with specific goals of instilling exercise habits in high school students and by making physical education a graduation requirement. While physical education was almost always substituted away with a math or science class under the old curriculum, the design of the new curriculum makes it impossible to avoid physical education classes.

The reform alleviated excessive academic burden on students by eliminating the mandatory block course structure where each student had to take the same required courses. Under the new curriculum, the workload in traditional core courses such as mathematics, physics, history, and so on, is significantly reduced. More specifically, the new curriculum reduced the classroom hours 
for the required courses and introduced elective courses. These elective courses cover almost all subjects, including core subjects such as mathematics, physics, biology, and chemistry. Students can also take elective courses in many other subject ranging from information technology to history to geography. Thus, students were provided with the option of taking courses in the subjects of their interest, rather than being forced to take a pre-determined sequence of classes. The new curriculum also introduced an "independent research studies" course which is designed to enhance students' skills for independent study and to cultivate their creativity. These major changes in curriculum arguably increased student learning by allowing students to focus on subject matters in which they are interested, and by reducing undue stress of a regimented curriculum.

We employ data from the Beijing College Students Panel Survey (BCSPS), which contains information on about 4,250 undergraduates from 15 universities in and around Beijing. ${ }^{5}$ Using a difference-in-difference strategy, we exploit cohort-varying exposure to the curriculum reform. In each province, younger students were exposed to the new reform while older students completed high school under the old curriculum. Students from different provinces were "treated" by the new curriculum in different years because provinces started their implementation of the new curriculum in different years (see Table 1).

We find that the new curriculum had a significant and positive effect on students' educational success in university and on their attitudes towards learning. Specifically, students who are exposed to the new curriculum in high school receive more " $A$ " grades in university, and they rank higher among their peers by grade point average in comparison to those who studied under the old curriculum. Students of the new curriculum are more likely to reveal a willingness

\footnotetext{
${ }^{5}$ Cantoni et al. (2017) used data on 1,954 undergraduate students from Peking University., and exploited cohort-varying exposure to the curriculum reform to identify the impact of the new curriculum on students' political views.
} 
to learn and to master the course material. These students are also more engaged in social activities (student clubs) in university, and have more confidence in their academic abilities, and more selfconfidence generally.

The new curriculum also made students more likely to retain a healthy body mass index, and less likely to have mental health issues such as feeling sad and melancholic, feeling depressed, feeling panicked, and feeling as though their own life has no value. Students who attended high school under the new curriculum are also happier. These results, taken together, indicate that the education reform had a significant impact on students’ academic success and well-being.

In Section II we provide the background regarding the curriculum reform in China (the Eighth Curriculum Reform). Empirical framework is explained in Section III. The data used in the paper are presented in Section IV. The empirical results and robustness checks of the results are reported in Section V and VI. Section VII is the conclusion.

\section{The Eighth Curriculum Reform in China}

\section{Timing of the Eighth Curriculum Reform}

The so-called Eighth Curriculum Reform, implemented by Chinese central government, aimed at substantially increasing the quality of basic education in the country. One of the primary goals of the reform was to abandon the rigorous exam-oriented education system, which had been widely criticized (Dello-Iacovo 2009). The Eighth Curriculum Reform is one of the most ambitious education reforms that aims to provide su shi jiao yu (quality education) in China. The reform covered the entire basic education system including preschool, compulsory education (primary school and middle school) and high school. In this paper we focus on the part of the curriculum reform that targeted high schools, the enactment of which began in 2004. 
The implementation of the high school curriculum reform took place in different years in different provinces. Following the preparation phase of the reform between 1999 and 2003, the high school curriculum reform was first formally implemented in 2004 in four provinces (Shandong, Hainan, Guangdong and Ningxia) in China. Other provinces and municipal cities joined the reform in succession in the following eight years until 2012.

In Table 1 we provide the year in which each province or municipal city started the implementation of the new high school curriculum. ${ }^{6}$ The beginning year of the reform's implementation in a province was not random. It depended on whether the provinces or municipal cities were ready in training teachers and providing supplemental materials (Cantoni et al. 2017). Although there is no clear pattern in the timing of the introduction of the new curriculum among the provinces, we conduct a variety of robustness tests and placebo analyses to verify that our results are not driven by endogenous rolling out of the program.

\section{Goals of the New Curriculum}

According to the "Basic Education Curriculum Reform Outline" of Education of China in 2001, the reform has some general targets including “developing students' initial creativity, practical capability, scientific and human accomplishment, and environmental consciousness," "shaping students with strong body and good psychological health; helping students form healthy aesthetic taste and life style," "shaping students with patriotism, collectivism

\footnotetext{
${ }^{6}$ Cantoni et al. (2017) write that the high school curriculum reform started in the Guangxi province in 2010. We find, however, that, the Guangxi province started implementing the curriculum reform in 2012. Specifically, Guangxi province issued the "Guangxi Regular High School Curriculum Reform Implementation Plan” in January 2012, announcing that Guangxi province would start the high school curriculum reform in that year. http://www.gxedu.gov.cn/Item/3318.aspx.

${ }^{7}$ The link to the document is: http://www.moe.gov.cn/srcsite/A26/jcj_kcjcgh/200106/t20010608_167343.html.
} 
and the love for socialism," and “equipping students with the conscience of socialist democracy, the rule of law and social responsibility,"8

There are six specific implementation goals of the reform as stated in the "Basic Education Curriculum Reform Outline”. These goals are outlined as (1) Change the existing curriculum, which puts too much emphasis on imparting knowledge to students, to a new curriculum to emphasize helping students form positive and active attitudes towards study. Make the process of learning become a process of acquiring the ability to learn and forming correct values for students; (2) Change the current curriculum, which contains too many subjects, to a more balanced comprehensive and selected curriculum. Adjust the curriculum to satisfy different needs of students in different areas in China; (3) Reduce the workload of students by removing the "hard, sophisticated, seldom-used and outdated” contents from courses. Pay attention to students' actual interest, and select the most fundamental knowledge and skills for students which could provide lifelong benefits to students; (4) Change the current style of cramming-teaching which only requires students to memorize and accept what is taught in class, and cultivate students' abilities in collecting and processing information, acquiring knowledge, analyzing and solving problems independently, as well as in communication and cooperation; (5) Employ the curriculum to improve students' development, teachers' teaching skills and class quality, instead of screening or selecting students; (6) Improve the adaptation of the curriculum to students and schools by changing the centralized management of curriculum to a 3-tier management at national, local and the school level.

\footnotetext{
${ }^{8}$ Whether the reform was successful in hitting the first target (shaping students with patriotism, collectivism and the love for socialism) was analyzed by Cantoni et al. (2017).
} 


\section{Specific Changes in the Curriculum}

Detailed implementation plans of the high school curriculum reform are stated in the "Regular High School Curriculum Project (Trial) ${ }^{9}$ " which were issued by the Ministry of Education of China in 2003. First, although the standard compulsory classes of the old curriculum (Chinese, foreign languages, mathematics, physics, chemistry, biology, history, politics and geography) are retained, subjects of general technology and information technology are added to the new curriculum. In addition, the new curriculum required students to enroll in new courses such as social practice and investigate studies, as well as community service. Second, the number of hours devoted to compulsory classes during high school are reduced substantially, and elective classes are introduced. Third, a credit system is introduced to determine the weight of each subject in the overall curriculum and to evaluate the performance of students. Specific requirements on the number of credits must be fulfilled in order for students to graduate from high school.

Under the old system, only those subjects which would be tested in the national university entrance exams were considered as necessary part of the curriculum. Thus, under the old curriculum students usually did not take or they took only a few of the so-called "subsidiary courses" such as music or physical education because these courses were not covered with China's national university entrance exam ${ }^{10}$. In contrast, the new curriculum made it mandatory for all students to take a specific number of minimum credits in all subject including physical education

\footnotetext{
${ }^{9}$ Official link of the document: http://www.moe.gov.cn/srcsite/A26/s8001/200303/t20030331 167349.html.
}

${ }^{10}$ In China, all students who wish to go to college must attend the national college entrance examination (negligible number of students may have the chance to be accepted by a university directly, without taking the college entrance exam, due to their special talents or awards received in national or international competitions). The total scores of a student in the exam decides whether the student will be accepted by a university or not. In the college entrance exams, all students are required to take exams on Chinese, math and English. If a student follows the Arts track in high school, then student also needs to take exams on the subjects of history, politics and geography. If a student follows the Science track in high school, the student also needs to take exams on the subjects of physics, chemistry and biology. 
and art. This meant that the new curriculum forced the students to take classes such as arts and physical education even though these classes are not the focus of the university entrance exams.

In the new curriculum subjects such as Chinese, mathematics and physics contain elective components, in addition to being compulsory. These elective courses cover additional topics that could be of interest to students. More generally, electives include two levels of courses. The socalled "Elective I" courses are required to be provided in all high schools, while schools are required to provide “Elective II” courses based on their local attributes and students’ interests. In these elective classes, students use separate textbooks which are different from the textbooks used in compulsory courses. This design allows students to have more freedom in the subjects they study compared to students who went to high school under the old curriculum.

In contrast to the old lock-step curriculum in which all student took the same, mandatory classes, the new curriculum established a credit system. Students earn 2 credits by studying a module (containing 36 classes, each of which is 45 minutes long) and they need to pass a test on the material covered in that module. The new curriculum requires students to complete a minimum number of credits in each compulsory subject and at least a certain amount of total credits in elective courses to graduate from high school. Students covered by the new curriculum are required to spend relatively more time on investigative studies, arts and physical education than on subjects such as physics and chemistry. For example, according to the new curriculum, the minimum number of credits required for chemistry (the compulsory section) is 6 during the three academic years in high school, while the number of credits required for arts, physical education and health, and investigative study are 6, 11 and 15, respectively. In addition, the new curriculum requires students to participate in comprehensive social activities (such as community service). All students are required to attend at least one week of social practice each year and they are also 
required to engage in at least 10 days of community service to earn credit. As a consequence, under the new curriculum, students have less workload in the traditional "major subjects” such as math, chemistry, history, etc., but have more time to devote to subject of their interest, to arts and do physical exercise. They also spend more time out of school to engage in social activities.

\section{Changes in Textbooks}

Along with the re-design of the curriculum, textbooks for all subjects were re-written. The new textbooks in all subjects changed dramatically in a number of dimensions, including the purpose, structure, content and difficulty. The new textbooks were designed under the guidance of the core goal of the curriculum reform to alter the exam-oriented focus, to increase students' interest in the subject matters and to cultivate the ability to study independently. For example, as stated in the "Curriculum Standards of Mathematics in Regular High School"11", one purpose of the new mathematics textbook is to help students develop the ability to acquire knowledge in mathematics independently, which was not the goal of the old version of the textbook. The contents of the new and old versions of the math textbooks are also different. In the new textbook of the compulsory math courses, only the most fundamental knowledge in mathematics is presented. A series of other topics in mathematics are covered in elective mathematics courses. These optional elective courses include topics on the history of mathematics, economic mathematics, the application of mathematics on information security and so on, which were not covered in old textbooks. The new math textbook also integrated the concept of mathematical modeling into

\footnotetext{
${ }^{11}$ It is issued by the Ministry of Education of China in 2003 and published by the People's Education Press. The People's Education Press provides the “curriculum standards” for all subjects on its official website. Here is the link to the "Curriculum Standards of Mathematics in Regular High School" (in Chinese): http://old.pep.com.cn/gzsx/jszx_1/czsxtbjxzy/xkbsyjc/gzsxkcbz/.
} 
every topic in the book to help develop students' creativity and capacity of thinking analytically. Similar significant changes can be found in the textbooks in all other subjects ${ }^{12}$.

\section{Teacher Training and Exams}

As part of the new curriculum reform teachers underwent extensive training to equip them with skills to teach the new curriculum. Local governments were asked to formulate and implement their own schedules to train teachers for the new curriculum. No teacher was allowed to work until he/she completed the training program. Besides fully understanding the new curriculum, teachers were instructed to develop better teaching skills and methods. Teachers were coached to cultivate in students the ability to work independently and motivate students to question, investigate, and research $^{13}$.

The "Basic Education Curriculum Reform Outline” states that a new student evaluation system should be established. Specifically, the goal of this new evaluation system is not only pay attention to students' scores in exams, but to also focus on students' potential in all dimensions, and to help students build their identify and self-confidence. To be consistent with the new curriculum, local education authorities started to change the national university entrance exam accordingly. For example, Shandong province (one of the first four provinces to employ the new

\footnotetext{
${ }^{12}$ As another example, in the physics textbook of the new curriculum students are only required to learn materials in mechanics and electricity, while under the old curriculum students were required to study mechanics, electricity, thermodynamics, optics and atoms. The Ministry of Education of China published the standard curriculum for regular high schools for 15 subjects (such as Chinese, math, English, physics, chemistry, physical education and health, arts, etc.) in 2003, which contain all the details of the curriculum for each subject.

${ }^{13}$ The detailed guidelines for teacher training are provided in the "Basic Education Curriculum Reform Outline" and the "Opinions from the Ministry of Education on Further Enhancement of Teacher Training for the New Basic Curriculum”, issued by the Ministry of Education of China.
} 
curriculum) changed the structure and contents of its university entrance exam in $2007^{14}$. A newly designed comprehensive test was added to the university entrance exam. This comprehensive test covered materials in the subjects of arts, technology (general and information), physical education and health, and so on. The comprehensive test accounts for 60 (out of 750) points of the university entrance exam ${ }^{15}$. Other provinces and municipal cities adjusted their university entrance exams as well.

\section{Empirical Strategy}

We employ a difference-in-difference strategy to investigate the causal effect of China's Eighth Curriculum Reform of High Schools on student outcomes in university by estimating the following specification:

$$
Y_{i j p}=\beta_{1}+\beta_{2} \text { New } \text { Curriculum }_{j p}+X^{\prime}{ }_{i j p} \boldsymbol{\beta}_{3}+\delta_{j}+\theta_{p}+\lambda_{c}+\gamma+\varepsilon_{i}
$$

where $Y_{i j p}$ stands for the outcome of university student $i$ who entered high school as part of cohort $j$ in province $p$. Outcomes include educational success of the student in university, measured by such variables as the number of courses in which the student received an "A," the current rank of the student in his/her class in university, whether the student skipped major classes last semester. Other outcomes include variables that gauge the extent of the student's enthusiasm for learning: whether the student wants to learn more from each class, and how much he/she wants to master the class materials. We also use as dependent variables two indicators of student's selfconfidence in their ability to learn: whether he/she is confident in mastering class material and

\footnotetext{
${ }^{14}$ The national university entrance exams in China are held by each province and municipal city. Some provinces and municipal cities may employ the same tests, but some areas administer their own tests.

${ }^{15}$ Details can be found in the "Guidance Plan for Regular College Admission in Shandong Province 2007”. http://kszy.jnjyw.edu.cn/kcgg/200412/795.html.
} 
whether the student is confident that he/she can solve the hardest problems in during the coursework.

Other dependent variables are indicators of physical and mental health (a healthy BMI, and various measures of mental well-being), the level of happiness of the student, and indicators of being self-content. Detailed definitions of the dependent variables are discussed below in the Data section.

Our main explanatory variable $\mathrm{New}$ Curriculum $_{j p}$ is an indicator that takes the value of one if cohort $j$ in province $p$ entered high school when the new curriculum was in effect. The coefficient $\beta$ captures the effect of the curriculum reform on the outcomes of interest; $\delta_{j}$ and $\theta_{p}$ stand for a set of high school cohort fixed effects and province fixed effects, respectively. $\lambda_{c}$ represents university fixed effects associated with the 15 universities in the sample, $\gamma$ is the fixed effect that distinguishes between two levels of students surveyed (freshmen and juniors), and $\varepsilon_{i}$ is the error term. Standard errors are clustered at provincexhigh school cohort level.

The vector $\mathbf{X}_{\mathrm{ijp}}$ contains demographics information of the students, including age, gender, ethnicity status, and single child status. Also included in $\mathrm{X}$ are variables related to the family background of the student including parents' educational level and self-reported family social status. Definitions of these covariates are displayed in Table 2.

The results are not confounded by fixed differences between provinces such as cultural factors, because such time-invariant differences are captured by province fixed-effects, and identification is obtained from cross-cohort variation within a province. Similarly, potential differences in attitudes and preferences across cohorts are filtered out by cohort fixed-effects. Furthermore, the students we analyze are only two years apart in age (ignoring the small group of irregular students, such as those who took the university entrance exam multiple times). As 
highlighted in Cantoni et al. (2017) who used the same identification strategy, the timing of the introduction of the new curriculum across provinces was not random, but differences between provinces and across cohorts are accounted for in the specification shown in Equation (1). Extensions of this specification are discussed later in the paper. Finally, we entertain the possibility that the introduction of the new curriculum might be a function of cohort-specific school spending. To account for this potential confounding, in some specifications we also control for province-and cohort-specific education spending per high school student when the student was in high school.

Table 1 presents information on the introduction of the new curriculum in each province. Columns (1) shows the year in which the province started implementing the new curriculum reform and column (2) presents the year when the first cohorts of students, who studied under the new curriculum, graduated from high school. High school graduation years are the same as university entry years. This is because the highs school ends in the Spring, university entrance exam takes place in June, and classes start in September.

\section{Data}

\section{Descriptive Statistics of the Sample}

The data set used in this study is the Beijing College Students Panel Survey (BCSPS) ${ }^{16}$. We employ the only publicly available wave of 2009. The sample contains university students who were surveyed towards the end of the Spring semester, in June 2009. The survey, by design, includes only freshmen and juniors. This means that students in the sample entered universities

16 The data can be downloaded from the Chinese National Survey Data Archive (CNSDA). http://www.cnsda.org/index.php?r=projects/view\&id=93659073. The survey is called CSDPS in the CNSDA. 
either in the Fall of 2006 or in the Fall of $2008^{17}$. Students were randomly sampled from 15 universities in and around Beijing (Li, 2016). These students entered high school in 2003 or 2005. The sample, however, also includes some students who entered high school in 2001, 2002 or 2004. These are the students who took the university entrance exam more than once, and are enrolled in a university after they (typically) took the exam one year after high school graduation. As we show later, dropping these students from the analysis has no impact on the results. We drop students from Tibet, Hong Kong, Taiwan and Macau from the analyses because they come from a completely different high school systems and curricula ${ }^{18}$.

Direct information on students' year of entry to high school is not available. We do, however, know the year in which each student took the national university entrance exam. We also know how many times the students took the exam. Because the university entrance exam is held once a year, we can accurately determine the year in which the student entered high school. Locations of students' high schools are also provided in the data set. Therefore, we can determine whether the students were treated by the new curriculum in high school based on the high school entrance year of the students, the location of the students' high school, and the timing of introduction of the new curriculum in each province and municipal cities ${ }^{19}$.

\footnotetext{
${ }^{17}$ By design of the survey, all students should be university freshmen and juniors. Nineteen students, however, reported that they were sophomores. Because the survey was conducted in June 2009, it might be the case that these students could have reported themselves as rising sophomores (who have completed their first year of university and will become sophomores in the Fall). It also may be the case that these students simply did not provide the correct answers. As we will explain later, in order to determine the high school cohort of the students, we need to know the current matriculation levels of the university students. Therefore, we drop these 19 students from the sample.

${ }^{18}$ A total of 38 observations (less than $1 \%$ of the sample) are dropped under all these restrictions. Including these observations do not affect the results.

${ }^{19}$ Shanghai did not participate in the eighth national curriculum reform. As the most developed area and the pioneer in education reform in China, Shanghai implemented its own curriculum reform in 1998 which had similar goals as the national curriculum reform (Yin, 2013; OECD, 2016-3). All students from
} 
In Table 2, we present the summary statistics of student attributes. As shown in column (1), only about eight percent of the sample went to high school under the new curriculum. This is because the survey was conducted in Summer 2009, and as displayed in Table 1, with the exception of Shanghai, the implementation of the reform did not start until 2004. This, in turn, implies that the students who studied under the new curriculum started graduating from high school in 2007 (with the exception of "treated" high school students from Shanghai, who started graduating in 2001). Thus, most students in the sample attended high school under the old curriculum. By design of the data collection, only university freshmen and juniors are surveyed, and 48 percent of the sample are juniors. Above Average Family Social Status is a dummy variable which takes the value of one if the student indicated that his/her family's social status is better or much better than the average in their city/town.

Columns (3) and (4) of Table 2 display the means of the variables by curriculum type, and reveal that some attributes are different between students who went to school under the old and the new curricula. Not surprisingly, those who studied under the old curriculum are about one year older on average, and they are more likely to be juniors in university (as opposed to being freshmen). Father education, family social status, and minority status are also different between the two groups. These raw differences disappear, however, when we control for province fixed effects and high school cohort fixed effects. As shown in Table 3, and as reported by Cantoni et al. (2017, Table 2), once we adjust for these fixed-effects, there is no difference in personal attributes of the students who were exposed to the new curriculum and those who studied under the old curriculum. Specifically, Table 3 displays the results of the exercise that investigates if the

Shanghai are considered as being treated by the new curriculum in the analyses. As shown in the paper, the results do not change when we exclude the students from Shanghai from the analysis. 
sample is balanced in student attributes by curriculum type. Each row presents the results from a different regression where the dependent variables are listed in columns (1) to (8) and the entries are the estimated coefficients and standard errors of the New Curriculum dummy. Each regression includes province and cohort fixed effects. The results of Table 3 indicate that exposure to the new curriculum is not correlated with student attributes ranging from age to gender to parental education.

\section{Dependent Variables}

The dependent variables measure students' educational outcomes in university, their confidence in their academic ability, level of happiness, healthy body mass index, mental health, self-confidence, and attitudes towards studying. The descriptive statistics of the outcome variables are provided in Table 4.

The variables that gauge the educational outcomes include the total number of " $A$ " grades received by the student during the first semester in university. The reason to ask this question as "first semester in university" is because about half of the sample are freshmen students and they were in their second semester when they took the survey (the survey was registered towards the end of the Spring semester). Thus, the grades in the spring semester of the freshmen year were not yet known when the survey was taken. Another variable measuring university success is student's current rank (by GPA) in university. Along the same lines, "Often Skipped Classes in Major Courses” is a dummy variable that takes the value of one if the student declared that he/she often skipped classes in major courses during the previous semester. "Number of Clubs Joined" stands for the number of student clubs the student has become a member of, representing student's sociability. 
There are two variables measuring attitudes towards studying. The variable "Wants to Learn as Much as Possible" takes the value of one if the student agreed or completely agreed with the statement "I want to learn as much knowledge as possible from classes." Similarly, "Strong desire to master course material" is another indicator variable that takes the value of one if the student agreed or completely agreed with that statement.

Students' confidence in their academic ability is measured by two dummy variables, which take the value of one if the students agreed or completely agreed with the statements "I believe I can master the knowledge and materials covered in class" and "I believe I can solve the hardest problem in class." Self-confidence is measured by two indicators based on whether the student agreed or completely agreed with the statements that "I tend to think myself as a loser" and "I hold a positive attitude towards myself." The student were also asked to rate their level of happiness on a 100 points scale where higher scores represents a higher level of happiness.

We employ 10 indicators of mental health. ${ }^{20}$ The survey asked the students to report how much they agree with the following statements regarding how they felt during the preceding week 1) "I feel sad and melancholic"; 2) "I feel depressed"; 3) "I feel that I can become unhappy easily"; 4) "I feel that there is nothing to expect for"; 5) "I lose interest in almost everything"; 6) "I feel that I cannot acquire any joy from what I do"; 7) "I feel panicked"; 8) "I feel perturbed"; 9) "I feel that my life has no value at all", 10) "I sometimes get scared for no reason." Potential answers to these questions include "Does not apply at all", "Sometimes applies", "Often applies" and "Completely applies". We created indicators that take the value of one if the corresponding answer was "often applies" or "completely applies." Averaging these 10 indicators of mental and

\footnotetext{
${ }^{20}$ There are additional questions in the survey that can be considered as indicators of mental health, albeit less obviously. Analyses of those questions are reported in the Appendix.
} 
emotional health, we created the variable Mental Health Index. Higher values indicate poorer mental health.

Physical well-being is measured using the Body Mass index (BMI). The data set includes information on the height and weight of each student. Using this information we calculated the BMI for each individual to determine if the BMI is in the healthy range of 18.5 to $23.9 .^{21} 22$

\section{Results}

The baseline results of our difference-in-difference estimations regarding the educational outcomes, confidence in academic ability and academic attitudes (willingness to learn) are presented in Table 5A. The results pertaining to physical and mental health, self-confidence and happiness are provided in Table 5B.

All regressions include province fixed effects high school cohort fixed effects, and a dummy to indicate that the student is a freshman. Standard errors are clustered at the province-bycohort level. The results, displayed in column (1) of Table 5A show that students who are exposed to the new curriculum receive about 0.5 more "A" grades in their first semester in university in comparison to students who attended high school under the old regime. Students treated by the new curriculum rank about 4 student higher in their class. The results also show that students who studied under the new curriculum join more clubs, and they are less likely to skip class although this last effect is not statistically different from zero.

\footnotetext{
${ }^{21}$ The range for healthy BMI (18.5-23.9) among Chinese is suggested by "Guidance for Preventing Overweight and Obesity among Chinese Adults" issued by the Ministry of Health of China.

${ }^{22}$ In our sample more than 99 percent of college students have a BMI lower than 30, which is the cutoff level for obesity. Thus, there would not be almost no variation in the dependent variable if we used obesity as an outcome.
} 
Table 5A also demonstrates that the new curriculum increased students' confidence in their academic ability and their eagerness to master the course material. Specifically, students who attended high school under the new curriculum are 6 to 7 percentage points (20 percent) more likely to indicate that they are confident that they can master the class material and that they can solve the hardest problems. They are about 4 percentage points (6 percent) more likely to reveal that they want to learn as much as possible, and 8 percentage points (14 percent) more likely to say that they have a strong desire to master the class material.

Column (2) of Table 5A adds individual controls to the baseline model. These variables are listed in Table 2. The inference does not change, which is not surprising as individual attributes are not expected to be correlated with the introduction of the new curriculum in the province. It may be argued that provinces that initiated the implementation of the new curriculum earlier than others did so because they had more resources in comparison to other provinces and that these resources, and not the curriculum itself, may have impacted student outcomes in university. To guard against this possibility, we obtained data on total education expenditures per high school student at the provincial level in each year. The data are from the China Educational Finance Statistical Yearbooks. We averaged the per pupil education expenditures over the 3 years in high school for each high school cohort in each province. ${ }^{23}$ Column (3) of Table 5A shows that controlling for per pupil education spending in high school has no impact on the estimated coefficients.

Table 5B presents the effect of the high school curriculum reform on students' happiness, physical health (whether their BMI is in the healthy range) and indicators of mental health when

\footnotetext{
${ }^{23}$ For example, for students who entered high school in 2003 in a given province, the educational spending for those students is the average educational spending in that province in between 2003 and 2005, the period during with the students were in high school.
} 
they are in university. The results indicate that students who studied under the new curriculum are happier in comparison to students who studied under the old curriculum. The magnitude of the difference is around one point from a baseline average of 83 points. We also find that students who went to high school under the new curriculum in high school are about 7 percentage points (10 percent) more likely to have a healthy body mass index.

Table 5B also presents the estimated effects of the new curriculum on various mental health indicators. Because we measure multiple aspects of mental health that are similar, we adjust the p-values for multiple comparisons using the improved Benforroni correction method of Simes (Simes 1986, Newson 2010, Benjamini and Yekutieli 2001). ${ }^{24}$ Adjusted $p$-values, which are presented in column (5), are only slightly larger than the unadjusted $p$-values in column (4), and they don't alter the inference. Studying under the new curriculum improves the mental health of the students. For example, those who studied under the new curriculum in high school are nine percentage points less likely to feel sad or melancholic, and they are 5 percentage points less likely to feel depressed. The magnitude of the impact of the new curriculum is about the same in other indicators of mental health, and new curriculum generates an improvement in overall mental health. Specifically, exposure to the new curriculum reduces the mental health index by four percentage points, which represents a 28 percent improvement in mental health (the mental health is the average of the 10 indicators mental health difficulties). Appendix Table A1 displays the results that use some other outcomes that arguably gauge mental stress of the student. The regressions are based on the specification used in column (3) of Table 5B. The results are in line with those reported in Table 6B.

${ }^{24}$ Examples of this implementation include Kottelenberg and Lehrer (2017) and Erten and Keskin (2018). 


\section{Robustness, Extensions, and Placebo Tests}

We implement a series of tests to evaluate the robustness of the results. We start with the investigation of the sensitivity of results to variations in sample composition. First, we exclude students from Shanghai. As discussed earlier, Shanghai implemented its own curriculum reform with similar goals in 1998. Thus, in models reported in Tables 5A and 5B, university students from Shanghai high schools are considered as being treated by the new curriculum. As shown in column (1) of Tables 6A and 6B, dropping 68 students from Shanghai did not alter the results.

Column (2) drops 243 students who enrolled at a university without taking the university entrance exam. High school students in China can get acceptance to universities by recommendation, without taking the university entrance exam. Some high schools have quotas to recommend students to particular universities. The primary mechanism is winning a prize in a competition in a subject such as Chinese, English, Math, etc. Students can also be recommended to universities for winning a title such as "outstanding student" or "outstanding student leader." In addition, students may get accepted by universities if they have learned some minority language. Excluding these students did not alter the results. Finally, Column (3) of Tables 6A and 6B excludes students who took the university exam multiple times. There are 723 students in this group, and dropping them had no impact on the results either.

Tables 7A and 7B investigate the sensitivity of the results to variations in model specification. As was the case in all previous models, each regression controls for province fixed effects, high school cohort fixed effects, university fixed effects, and an indicator to control for whether the student is a freshman or junior in university. Column (1) in Tables 7A and 7B presents the results displayed in column (3) Tables 5A and 5B for comparison purposes. These models include student attributes as well as education spending per high school student in the province of 
the student when the student was in high school. Column (2) adds time-varying province-level controls. They are the size of the cohort (the number of students) entering high school in the province, and per capita income of the province when the cohorts entered high school. The results do not change.

It could be the case the income differences between provinces before the implementation of the curriculum reform (in 2003) could be systematically related to differences across cohorts. Thus, Column (3) controls for cohort fixed effects interacted with per capita income in student's province in 2003 (the year before the beginning of the reform implementation). The results are not impacted by this modification either.

To investigate if student attributes are different between the old vs. new curricula, we used the student characteristics used in the regressions to predict our outcome variables, and tested whether the predicted outcomes were different between the curricula. The result of this exercise, displayed in Appendix Table A2 indicates that the impact of the new curriculum on predicted outcomes is indistinguishable from zero.

As an additional robustness check we investigated whether students from a particular province were driving the results. To do that, we estimated the benchmark model shown in column (3) of Tables 5A and 5B by dropping one province at a time. Panels of Figure 1 displays the estimated coefficients with their 90-percent confidence intervals. As shown in Figure 1, the results are not driven by a particular province.

Cantoni et al. (2017) analyzed the impact of the same curriculum reform on political beliefs of students who attend Peking University and found that the reform shaped the beliefs of these students. Our sample differs from theirs as we have students from 15 different universities. To investigate if we obtain a similar result in our sample, we employ two variables that measure the 
degree to which the students are satisfied with China's current level of development, and how optimistic they are about China's future economic development. This analysis uses as dependent variables the scores (from 0 to 100) assigned by the students to two questions: "How satisfied are you with China's current level of development in all aspects?" and "How optimistic are you about the prospect of China's development in all aspects in the future?"

Appendix Table A3 shows that the new high school curriculum enhances students' optimism about China's current and future economic development. Those university students who studied under the new curriculum are about 2 percent more satisfied with China's current economic conditions in comparison to students who studies under the old curriculum, and they are 3 percent more optimistic about China’s future economic development.

As a placebo test, we randomly assigned the years of the introduction of the new curricula to the provinces in the sample. Specifically, we used the actual implementation dates and randomly assigned them to the provinces in our sample without replacement. We repeated this process with 10,000 placebo treatments and estimated the outcomes using the benchmark specifications employed in column (3) of Tables 5A and 5B. We plot the distribution of the tstatistics obtained from these 10,000 random placebo treatments in Figure 2. The vertical line in each figure marks the location of the t-statistic obtained from the actual treatment (based on the results rein column 3 of Tables 5A and 5B). Each panel of Figure 2 also displays the share of the t-statistics obtained from placebo regressions that is larger than the actual t-statistic. The results show that randomly assigning placebo treatments provide very different results when the actual tvalues estimated in the papers indicated significant effects. These results, taken together, indicate that the findings reported in the paper are robust, and that they are not an artifact of confounders. 


\section{Conclusion}

In this paper we investigate the causal effect of a high school curriculum reform in China on students' educational outcomes in university, as well as on their happiness, mental and physical health, self-confidence, confidence in their academic ability, and attitudes towards learning. The reform, the implementation of which started in 2004, covered all provinces of China and it was rolled out in different years in different provinces.

The new curriculum, which is major overhaul, pivoted away from the old lock-step course structure where all students took the same required courses and only those subjects that were covered in the national university entrance exam were considered important. In contrast, the reform introduced a course credit system, changed the textbooks, and significantly modified the way in which classes are taught, and allowed the students to take elective courses in many subjects. The new curriculum also introduced an "independent research studies" course which is designed to enhance students' skills for independent study and to cultivate their creativity.

In addition, the new curriculum made such courses as arts (music and painting) and physical education mandatory and a graduation requirement. The new curriculum also placed emphasis on physical education with specific goals of instilling exercise habits in high school students, and by making it impossible to replace a physical education class with math or science classes, which had been the typical practice under the old curriculum to better prepare the students for the high-stakes university entrance exam.

Using survey data on students from 15 universities and employing a difference-indifferences strategy, we exploit cohort-varying exposure to the curriculum reform. We find that the curriculum reform had a significant and positive effect on all student outcomes analyzed. Specifically, students who were exposed to the new curriculum in high school have better 
academic performance in university. Students of the new curriculum are more likely to reveal a willingness to learn and to master the course material. These students are also more engaged in social activities (student clubs) in university, they have more confidence in their academic ability, and more overall self-confidence.

The reform not only improved students' educational success in university, but it also improved students' mental health by making them less likely to have problems such as feeling depressed, feeling panicked, or feeling as though their own life has no value. The new curriculum, which included a strictly-enforced physical education requirement, made students more likely to retain a healthy body mass index. Finally, students who attended high school under the new curriculum are also happier.

A number of sensitivity analyses demonstrate the robustness of the results, and indicate that high school curriculum has a significant impact on students' academic success and mental and physical well-being by allowing them to focus on subject matters in which they are interested, and by reducing undue stress of a regimented structure. 


\section{References}

Altonji, Joseph, 1995. “The Effects of High School Curriculum on Education and Labor Market Outcomes”, Journal of Human Resources, vol. 30, pp. 409-438.

Altonji, Joseph G., Blom, Erica and Meghir, Costas, 2012. "Heterogeneity in Human Capital Investments: High School Curriculum, College Major, and Careers”, Annual Review of Economics, vol. 4, pp. 185-223.

Benjamini, Yoav and Yekutieli, Daniel, 2001. "The Control of the False Discovery Rate in Multiple Testing under Dependency”, The Annals of Statistics, vol. 29, pp. 1165-1188.

Bernheim, B. Douglas, Garrett, Daniel M. and Maki, Dean M., 2001. "Education and Saving: The Long-Term Effects of High School Financial Curriculum Mandates”, Journal of Public Economics, vol. 80, pp. 435-465.

Brian, Jacob, Dynarski, Susan, Frank, Kenneth and Schneider, Barbara, 2017. "Are Expectations Alone Enough? Estimating the Effect of a Mandatory College-Prep Curriculum in Michigan”, Educational Evaluation and Policy Analysis, vol. 39, pp. 333-360.

Brown, Meta, Grigsby, John, van der Klaauw, Wilbert, Wen, Jaya and Zafar, Basit, 2016. "Financial Education and the Debt Behavior of the Young", The Review of Financial Studies, vol. 29, pp. 2490-2522.

Cantoni, Davide, Chen, Yuyu, Yang, David Y., Yuchtman, Noam and Zhang, Y. Jane, 2017. “Curriculum and Ideology”, Journal of Political Economy, vol. 125, pp. 338-392.

Card, David, 1999. “The Causal Effect of Education on Earnings”, Handbook of Labor Economics, vol. 3, pp. 1801-1863.

Cawley, John, Han, Euna, Kim, Jiyoon and Norton, Edward C., 2017. “Testing for Peer Effects Using Genetic Data”, NBER Working Paper, No. 23719.

Clotfelter, Charles T., Ladd, Helen F. and Vigdor, Jacob L., 2015. “The Aftermath of Accelerating Algebra Evidence from District Policy Initiatives”, Journal of Human Resources, vol. 50, pp. 159-188.

Cole, Shawn, Paulson, Anna and Shastry, Gauri Kartini, 2016. "High School Curriculum and Financial Outcomes: The Impact of Mandated Personal Finance and Mathematics Courses”, Journal of Human Resources, vol. 51, pp. 656-698.

Cortes, Kalena E., Goodman, Joshua S. and Nomi, Takako, 2015. "Intensive Math Instruction and Educational Attainment”, Journal of Human Resources, vol. 50, pp. 108-158.

Dello-Iacovo, Belinda, 2009. “Curriculum Reform and 'Quality Education' in China: An Overview”, International Journal of Educational Development, vol. 29, pp. 241-249.

Eren, Ozkan and Henderson, Daniel J., 2008. “The Impact of Homework on Student Achievement”, Econometrics Journal, vol. 11, pp. 326-348. 
Erten, Bilge and Keskin, Pinar, 2018. "For Better or for Worse?: Education and the Prevalence of Domestic Violence in Turkey”, American Economic Journal: Applied Economics, vol. 10, pp. 64-105.

Joensen, Juanna Schrøter and Helena Skyt, Nielsen, 2009. "Is There A Causal Effect of High School Math on Labor Market Outcomes?”, Journal of Human Resources, vol. 44, pp. 171198.

Kottelenberg, Michael and Lehrer, Steven, 2017. "Targeted or Universal Coverage? Assessing Heterogeneity in the Effects of Universal Child Care”, Journal of Labor Economics, vol. 35, 609-653.

Lavy, Victor, 2015. “Do Differences in Schools' Instruction Time Explain International Achievement Gaps? Evidence from Developed and Developing Countries”, The Economic Journal, vol. 125, pp. F397-F424.

Levine, Phillip B. and Zimmerman, David J., 1995. “The Benefit of Additional High-School Math and Science Classes for Young Men and Women”, Journal of Business \& Economic Statistics, vol. 13, pp. 137-149.

Li, Zhonglu, 2016. "Family Background, Academic Performance and Admission to Postgraduate Study in China”, Chinese Journal of Sociology (a Chinese Journal), vol. 36, pp. 86-109.

Long, Mark C., Conger, Dylan and Iatarola, Patrice, 2012. "Effects of High School Course-Taking on Secondary and Postsecondary Success”, American Educational Research Journal, vol. 49, pp. 285-322.

Meghir, Costas and Rivkin, Steven, 2011. “Econometric Methods for Research in Education”, Handbook of the Economics of Education, vol. 3, pp. 1-87.

Newson, Roger B., 2010. “Frequentist Q-Values for Multiple-Test Procedures”, The Stata Journal, vol. 10, pp. 569-584.

OECD, 2016. “Education in China: A Snapshot”. OECD 2016-3.

Pischke, Jörn-Steffen, 2007. "The Impact of Length of the School Year on Student Performance and Earnings: Evidence from the German Short School Years”, The Economic Journal, vol. 117, pp. 1216-1242.

Rose, Heather, and Betts, Julian R., 2004. "The Effect of High School Courses on Earnings”, The Review of Economics and Statistics, vol. 86, pp. 497-513.

Simes, R.J., 1986. “An Improved Bonferroni Procedure for Multiple Tests of Significance”, Biometrika, vol. 73, pp. 751-754.

Yin, Hongbiao, 2013. "Implementing the National Curriculum Reform in China: A Review of the Decade”, Frontiers of Education in China, vol. 8, pp. 331-359. 
Table 1

Staggered Implementation of the Eighth Curriculum Reform in China

\begin{tabular}{lcc}
\hline \hline & $\begin{array}{c}\text { Year in which the } \\
\text { Curriculum } \\
\text { Reform Was } \\
\text { Provinces and Municipal Cities }\end{array}$ & $\begin{array}{c}\text { Graduation Year of the } \\
\text { First High School Cohort } \\
\text { Studying under the New } \\
\text { Curriculum } \\
(2)\end{array}$ \\
\hline Shanghai & 1998 & 2001 \\
Guangdong, Hainan, Ningxia, Shandong & 2004 & 2007 \\
Jiangsu & 2005 & 2008 \\
Anhui, Fujian, Liaoning, Tianjin, Zhejiang & 2006 & 2009 \\
Beijing, Heilongjiang, Hunan, Jilin, Shan’xi & 2007 & 2010 \\
Henan, Jiangxi, Shanxi, Xinjiang & 2008 & 2011 \\
Hebei, Hubei, Inner Mongolia, Yunnan & 2009 & 2012 \\
Chongqing, Gansu, Guizhou, Qinghai, Sichuan & 2010 & 2013 \\
Guangxi & 2012 & 2015 \\
\hline
\end{tabular}


Table 2

Descriptive Statistics of Explanatory Variables

\begin{tabular}{|c|c|c|c|c|c|c|}
\hline \multirow[b]{2}{*}{ Variables } & \multirow[b]{2}{*}{ Description } & \multicolumn{2}{|c|}{ All } & \multirow{2}{*}{$\begin{array}{c}\text { New } \\
\text { Curriculum } \\
\text { Mean } \\
(3) \\
\end{array}$} & \multirow{2}{*}{$\begin{array}{c}\text { Old } \\
\text { Curriculum } \\
\text { Mean } \\
(4) \\
\end{array}$} & \multirow{2}{*}{$\begin{array}{l}\text {-value of } \\
\text { (3) - (4) } \\
\text { (5) }\end{array}$} \\
\hline & & $\begin{array}{l}\text { Mean } \\
(1)\end{array}$ & $\begin{array}{l}\text { Std. Dev. } \\
\text { (2) }\end{array}$ & & & \\
\hline New Curriculum & $\begin{array}{l}\text { Dummy variable }(=1) \text { if the student studied } \\
\text { under the new curriculum. }\end{array}$ & 0.075 & 0.264 & 1 & 0 & $\ldots$ \\
\hline Age & Age of the student. & 20.52 & 1.315 & 19.74 & 20.58 & 0.000 \\
\hline Female & Dummy variable $(=1)$ if the student is female. & 0.468 & 0.499 & 0.444 & 0.470 & 0.360 \\
\hline Minority & $\begin{array}{l}\text { Dummy variable }(=1) \text { if the student is from an } \\
\text { ethnic minority group in China. }\end{array}$ & 0.107 & 0.309 & 0.047 & 0.112 & 0.000 \\
\hline Single Child & $\begin{array}{l}\text { Dummy variable }(=1) \text { if the student is a single } \\
\text { child. }\end{array}$ & 0.641 & 0.480 & 0.684 & 0.637 & 0.093 \\
\hline Junior Student & $\begin{array}{l}\text { Dummy variable (=1) if the student is a junior in } \\
\text { university. }\end{array}$ & 0.482 & 0.500 & 0.106 & 0.513 & 0.000 \\
\hline $\begin{array}{l}\text { Father 's Education } \\
\text { High School or } \\
\text { Higher }\end{array}$ & $\begin{array}{l}\text { Dummy variable }(=1) \text { if the student's father has } \\
\text { at least a high school diploma. }\end{array}$ & 0.693 & 0.461 & 0.756 & 0.688 & 0.011 \\
\hline $\begin{array}{l}\text { Mother's Education } \\
\text { High School or } \\
\text { Higher }\end{array}$ & $\begin{array}{l}\text { Dummy variable }(=1) \text { if the student's mother has } \\
\text { at least a high school diploma. }\end{array}$ & 0.619 & 0.486 & 0.656 & 0.616 & 0.152 \\
\hline $\begin{array}{l}\text { Above Average } \\
\text { Family Social } \\
\text { Status }\end{array}$ & $\begin{array}{l}\text { Dummy variable }(=1) \text { if the student's self- } \\
\text { reported family social status is above the local } \\
\text { average. }\end{array}$ & 0.210 & 0.407 & 0.250 & 0.207 & 0.067 \\
\hline $\mathrm{N}$ & & 4,245 & & 320 & 3,925 & \\
\hline
\end{tabular}


Table 3

Balance of Personal Attributes

\begin{tabular}{|c|c|c|c|c|}
\hline Variables & $\begin{array}{l}\text { (1) } \\
\text { Age }\end{array}$ & $\begin{array}{c}(2) \\
\text { Female }\end{array}$ & $\begin{array}{c}\text { (3) } \\
\text { Minority }\end{array}$ & $\begin{array}{c}(4) \\
\text { Single Child }\end{array}$ \\
\hline New Curriculum & $\begin{array}{c}0.080 \\
(0.071)\end{array}$ & $\begin{array}{c}0.057 \\
(0.047)\end{array}$ & $\begin{array}{c}0.019 \\
(0.028)\end{array}$ & $\begin{array}{l}-0.010 \\
(0.043)\end{array}$ \\
\hline $\begin{array}{l}p \text {-value } \\
\mathrm{N}\end{array}$ & $\begin{array}{l}0.259 \\
4,245\end{array}$ & $\begin{array}{l}0.225 \\
4,245\end{array}$ & $\begin{array}{l}0.496 \\
4,245\end{array}$ & $\begin{array}{l}0.811 \\
4,245\end{array}$ \\
\hline & (5) & (6) & (7) & (8) \\
\hline Variables & Junior Student & $\begin{array}{l}\text { Father High } \\
\text { School or } \\
\text { Above }\end{array}$ & $\begin{array}{l}\text { Mother High } \\
\text { School or } \\
\text { Above }\end{array}$ & $\begin{array}{l}\text { Good Family } \\
\text { Social Status }\end{array}$ \\
\hline New Curriculum & $\begin{array}{c}0.003 \\
(0.003)\end{array}$ & $\begin{array}{c}0.024 \\
(0.043)\end{array}$ & $\begin{array}{l}-0.010 \\
(0.045)\end{array}$ & $\begin{array}{l}-0.039 \\
(0.038)\end{array}$ \\
\hline $\begin{array}{l}p \text {-value } \\
\mathrm{N}\end{array}$ & $\begin{array}{l}0.385 \\
4,245\end{array}$ & $\begin{array}{l}0.573 \\
4,245\end{array}$ & $\begin{array}{l}0.828 \\
4,245\end{array}$ & $\begin{array}{l}0.306 \\
4,245\end{array}$ \\
\hline
\end{tabular}


Table 4

Descriptive Statistics of Dependent Variables

\begin{tabular}{|c|c|c|c|c|c|}
\hline Variables & Description & $\begin{array}{l}\text { All } \\
(1) \\
\end{array}$ & $\begin{array}{c}\text { New } \\
\text { Curriculum } \\
(2) \\
\end{array}$ & $\begin{array}{c}\text { Old } \\
\text { Curriculum } \\
(3) \\
\end{array}$ & $\begin{array}{c}\text { p-value } \\
\text { (4) }\end{array}$ \\
\hline \multicolumn{6}{|l|}{ Educational Outcomes } \\
\hline $\begin{array}{l}\text { Number of "A" } \\
\text { Grades }\end{array}$ & $\begin{array}{l}\text { Total number of "A" grades received by the } \\
\text { student in the first semester of university. }\end{array}$ & $\begin{array}{c}3.186 \\
(2.653)\end{array}$ & $\begin{array}{c}3.561 \\
(2.474)\end{array}$ & $\begin{array}{l}3.155 \\
(2.66)\end{array}$ & 0.009 \\
\hline $\begin{array}{l}\text { Current Rank in } \\
\text { University }\end{array}$ & $\begin{array}{l}\text { Student's current rank in their cohort by } \\
\text { GPA. }\end{array}$ & $\begin{array}{l}14.78 \\
(1.00)\end{array}$ & $\begin{array}{l}13.15 \\
(8.74)\end{array}$ & $\begin{array}{l}14.90 \\
(11.5)\end{array}$ & 0.008 \\
\hline $\begin{array}{l}\text { Often Skipped } \\
\text { Classes in Major } \\
\text { Courses }\end{array}$ & $\begin{array}{l}\text { Dummy }(=1) \text { if the student often skipped } \\
\text { class in major courses during the last } \\
\text { semester. }\end{array}$ & $\begin{array}{c}0.071 \\
(0.257)\end{array}$ & $\begin{array}{c}0.040 \\
(0.196)\end{array}$ & $\begin{array}{c}0.074 \\
(0.261)\end{array}$ & 0.036 \\
\hline $\begin{array}{l}\text { Number of Clubs } \\
\text { Joined }\end{array}$ & $\begin{array}{l}\text { Total number of clubs the student joined } \\
\text { during university. }\end{array}$ & $\begin{array}{l}2.511 \\
(1.93)\end{array}$ & $\begin{array}{c}2.769 \\
(1.767)\end{array}$ & $\begin{array}{c}2.490 \\
(1.987)\end{array}$ & 0.015 \\
\hline \multicolumn{6}{|l|}{$\begin{array}{l}\text { Attitudes Towards } \\
\text { Studying }\end{array}$} \\
\hline $\begin{array}{l}\text { Wants to Learn as } \\
\text { Much as Possible }\end{array}$ & $\begin{array}{l}\text { Dummy }(=1) \text { if the student agrees or } \\
\text { completely agrees with the statement "I want } \\
\text { to learn as much as possible from class" }\end{array}$ & $\begin{array}{c}0.698 \\
(0.459)\end{array}$ & $\begin{array}{c}0.769 \\
(0.422)\end{array}$ & $\begin{array}{c}0.692 \\
(0.462)\end{array}$ & 0.004 \\
\hline $\begin{array}{l}\text { Strong Desire to } \\
\text { Master Course } \\
\text { Material }\end{array}$ & $\begin{array}{l}\text { Dummy }(=1) \text { if the student agrees or } \\
\text { completely agrees with the statement "I } \\
\text { would like to master the material covered in } \\
\text { course" }\end{array}$ & $\begin{array}{c}0.567 \\
(0.496)\end{array}$ & $\begin{array}{c}0.653 \\
(0.477)\end{array}$ & $\begin{array}{c}0.559 \\
(0.497)\end{array}$ & 0.001 \\
\hline \multicolumn{6}{|l|}{$\begin{array}{l}\text { Confidence in } \\
\text { Academic Ability }\end{array}$} \\
\hline $\begin{array}{l}\text { Confidence in } \\
\text { Mastering Course } \\
\text { Material }\end{array}$ & $\begin{array}{l}\text { Dummy }(=1) \text { if the student agrees or } \\
\text { completely agrees with the statement "I } \\
\text { believe I can master the knowledge and } \\
\text { materials covered in the course" }\end{array}$ & $\begin{array}{c}0.311 \\
(0.463)\end{array}$ & $\begin{array}{c}0.338 \\
(0.474)\end{array}$ & $\begin{array}{c}0.309 \\
(0.462)\end{array}$ & 0.282 \\
\hline $\begin{array}{l}\text { Confidence in } \\
\text { Solving the } \\
\text { Hardest Problems }\end{array}$ & $\begin{array}{l}\text { Dummy }(=1) \text { if the student agrees or } \\
\text { completely agrees with the statement "I } \\
\text { believe I can solve the hardest problems in } \\
\text { whatever I am studying" }\end{array}$ & $\begin{array}{c}0.565 \\
(0.496)\end{array}$ & $\begin{array}{c}0.594 \\
(0.492)\end{array}$ & $\begin{array}{c}0.562 \\
(0.496)\end{array}$ & 0.275 \\
\hline \multicolumn{6}{|l|}{ Self-Confidence } \\
\hline $\begin{array}{l}\text { Thinks of } \\
\text { Him/Herself as a } \\
\text { Loser }\end{array}$ & $\begin{array}{l}\text { Dummy }(=1) \text { if the student agrees or } \\
\text { completely agrees with the statement "I tend } \\
\text { to think of myself as a loser". }\end{array}$ & $\begin{array}{c}0.071 \\
(0.257)\end{array}$ & $\begin{array}{c}0.060 \\
(0.237)\end{array}$ & $\begin{array}{c}0.072 \\
(0.258)\end{array}$ & 0.409 \\
\hline $\begin{array}{l}\text { Holds Positive } \\
\text { Attitudes towards } \\
\text { Him/Herself }\end{array}$ & $\begin{array}{l}\text { Dummy }(=1) \text { if the student agrees or } \\
\text { completely agrees with the statement "I have } \\
\text { positive attitudes towards myself" }\end{array}$ & $\begin{array}{c}0.772 \\
(0.419)\end{array}$ & $\begin{array}{c}0.806 \\
(0.396)\end{array}$ & $\begin{array}{c}0.770 \\
(0.421)\end{array}$ & 0.141 \\
\hline \multicolumn{6}{|l|}{ Well-Being } \\
\hline Healthy BMI & $\begin{array}{l}\text { Dummy }(=1) \text { if the student's BMI is between } \\
18.5 \text { and } 23.9 \text {. }\end{array}$ & $\begin{array}{c}0.699 \\
(0.459)\end{array}$ & $\begin{array}{c}0.752 \\
(0.432)\end{array}$ & $\begin{array}{c}0.694 \\
(0.461)\end{array}$ & 0.030 \\
\hline $\begin{array}{l}\text { Feels Sad and } \\
\text { Melancholic }\end{array}$ & $\begin{array}{l}\text { Dummy }(=1) \text { if the student finds the } \\
\text { statement "I feel sad and melancholic" } \\
\text { applicable to him/her often or always. }\end{array}$ & $\begin{array}{c}0.193 \\
(0.395)\end{array}$ & $\begin{array}{c}0.176 \\
(0.381)\end{array}$ & $\begin{array}{c}0.194 \\
(0.396)\end{array}$ & 0.413 \\
\hline
\end{tabular}


Table 4 continued

\begin{tabular}{|c|c|c|c|c|c|}
\hline Variables & Description & $\begin{array}{l}\text { All } \\
(1)\end{array}$ & $\begin{array}{l}\text { New } \\
\text { Curriculum } \\
\quad(2)\end{array}$ & $\begin{array}{l}\text { Old } \\
\text { Curriculum } \\
\text { (3) }\end{array}$ & $\begin{array}{c}p \text {-value } \\
(4)\end{array}$ \\
\hline Feels Depressed & $\begin{array}{l}\text { Dummy }(=1) \text { if the student finds the } \\
\text { statement "I feel depressed" applicable to } \\
\text { him/her often or always. }\end{array}$ & $\begin{array}{c}0.126 \\
(0.332)\end{array}$ & $\begin{array}{c}0.119 \\
(0.324)\end{array}$ & $\begin{array}{c}0.127 \\
(0.333)\end{array}$ & 0.683 \\
\hline $\begin{array}{l}\text { Becomes Unhappy } \\
\text { Easily }\end{array}$ & $\begin{array}{l}\text { Dummy }(=1) \text { if the student finds the } \\
\text { statement "I feel that I can become unhappy } \\
\text { easily" applicable to him/her often or always. }\end{array}$ & $\begin{array}{c}0.292 \\
(0.455)\end{array}$ & $\begin{array}{c}0.285 \\
(0.452)\end{array}$ & $\begin{array}{c}0.292 \\
(0.455)\end{array}$ & 0.799 \\
\hline $\begin{array}{l}\text { Feels that There is } \\
\text { Nothing to Expect } \\
\text { for }\end{array}$ & $\begin{array}{l}\text { Dummy }(=1) \text { if the student finds the } \\
\text { statement "I feel that there is nothing to } \\
\text { expect for" applicable to him/her often or } \\
\text { always. }\end{array}$ & $\begin{array}{c}0.110 \\
(0.313)\end{array}$ & $\begin{array}{c}0.091 \\
(0.288)\end{array}$ & $\begin{array}{c}0.111 \\
(0.315)\end{array}$ & 0.259 \\
\hline $\begin{array}{l}\text { Loses Interest in } \\
\text { Almost Everything }\end{array}$ & $\begin{array}{l}\text { Dummy }(=1) \text { if the student finds the } \\
\text { statement "I feel that I almost lose interest in } \\
\text { everything" applicable to him/her often or } \\
\text { always. }\end{array}$ & $\begin{array}{c}0.059 \\
(0.235)\end{array}$ & $\begin{array}{c}0.028 \\
(0.166)\end{array}$ & $\begin{array}{c}0.061 \\
(0.240)\end{array}$ & 0.016 \\
\hline $\begin{array}{l}\text { Cannot Acquire Joy } \\
\text { from Anything }\end{array}$ & $\begin{array}{l}\text { Dummy }(=1) \text { if the student finds the } \\
\text { statement "I feel that I cannot acquire any joy } \\
\text { from what I do" applicable to him/her often } \\
\text { or always. }\end{array}$ & $\begin{array}{c}0.127 \\
(0.333)\end{array}$ & $\begin{array}{c}0.125 \\
(0.332)\end{array}$ & $\begin{array}{c}0.128 \\
(0.334)\end{array}$ & 0.913 \\
\hline Feels Panic & $\begin{array}{l}\text { Dummy }(=1) \text { if the student finds the } \\
\text { statement "I feel panic" applicable to } \\
\text { him/her often or always. }\end{array}$ & $\begin{array}{c}0.042 \\
(0.202)\end{array}$ & $\begin{array}{c}0.028 \\
(0.166)\end{array}$ & $\begin{array}{c}0.043 \\
(0.204)\end{array}$ & 0.190 \\
\hline Feels Perturbed & $\begin{array}{l}\text { Dummy }(=1) \text { if the student finds the } \\
\text { statement of "I feel perturbed" applicable to } \\
\text { him/her often or always. }\end{array}$ & $\begin{array}{c}0.074 \\
(0.262)\end{array}$ & $\begin{array}{c}0.069 \\
(0.254)\end{array}$ & $\begin{array}{c}0.075 \\
(0.263)\end{array}$ & 0.706 \\
\hline $\begin{array}{l}\text { Feels that Life Has } \\
\text { No Value }\end{array}$ & $\begin{array}{l}\text { Dummy }(=1) \text { if the student finds the } \\
\text { statement "I feel that my life has no value" } \\
\text { applicable to him/her often or always. }\end{array}$ & $\begin{array}{c}0.048 \\
(0.214)\end{array}$ & $\begin{array}{c}0.034 \\
(0.183)\end{array}$ & $\begin{array}{c}0.049 \\
(0.216)\end{array}$ & 0.237 \\
\hline $\begin{array}{l}\text { Feels Scared for No } \\
\text { Reason }\end{array}$ & $\begin{array}{l}\text { Dummy }(=1) \text { if the student finds the } \\
\text { statement "I sometimes feel scared for no } \\
\text { reason" applicable to him/her often or } \\
\text { always. }\end{array}$ & $\begin{array}{c}0.094 \\
(0.291)\end{array}$ & $\begin{array}{c}0.094 \\
(0.292)\end{array}$ & $\begin{array}{c}0.094 \\
(0.291)\end{array}$ & 0.510 \\
\hline Mental Health Index & $\begin{array}{l}\text { Mean of the } 10 \text { mental health indicators } \\
\text { listed above. }\end{array}$ & $\begin{array}{c}0.139 \\
(0.186)\end{array}$ & $\begin{array}{c}0.128 \\
(0.173)\end{array}$ & $\begin{array}{c}0.140 \\
(0.187)\end{array}$ & 0.294 \\
\hline Happiness Index & $\begin{array}{l}\text { Self-reported level of happiness rated on a 0- } \\
100 \text { scale (100 = completely happy). }\end{array}$ & $\begin{array}{c}83.85 \\
(11.58) \\
\end{array}$ & $\begin{array}{c}83.71 \\
(11.64) \\
\end{array}$ & $\begin{array}{c}83.86 \\
(11.57) \\
\end{array}$ & 0.871 \\
\hline
\end{tabular}

The sample size is the same as those in Table 5A and Table 5B. Means of the dependent variables are presented for the whole sample, treatment group and the control group separately, with standard deviations parentheses. The $p$-values of the t-tests of the differences between sample means for the treatment group and control group are reported in the last column in the table, without controlling for any covariates. 
Table 5A

The Effect of the Curriculum Reform on Education Outcomes, Self-Confidence, and Membership in Student Clubs

\begin{tabular}{|c|c|c|c|c|}
\hline Outcomes & $(1)$ & $(2)$ & (3) & $\begin{array}{c}\text { \# of Obs. } \\
\text { (4) }\end{array}$ \\
\hline Number of “A” Grades & $\begin{array}{c}0.527 * * * \\
(0.140)\end{array}$ & $\begin{array}{c}0.484^{* * *} \\
(0.145)\end{array}$ & $\begin{array}{c}0.470^{* * *} \\
(0.156)\end{array}$ & 4,195 \\
\hline Current Rank in University & $\begin{array}{c}-4.159 * * * \\
(0.893)\end{array}$ & $\begin{array}{c}-3.914 * * * \\
(0.918)\end{array}$ & $\begin{array}{c}-3.785 * * * \\
(0.940)\end{array}$ & 4,122 \\
\hline Often Skipped Classes in Major Courses & $\begin{array}{l}-0.027 \\
(0.019)\end{array}$ & $\begin{array}{l}-0.021 \\
(0.020)\end{array}$ & $\begin{array}{l}-0.017 \\
(0.020)\end{array}$ & 3,953 \\
\hline Number of Clubs Joined & $\begin{array}{c}0.376^{* * * *} \\
(0.089)\end{array}$ & $\begin{array}{c}0.371 * * * \\
(0.093)\end{array}$ & $\begin{array}{c}0.411^{* * *} \\
(0.094)\end{array}$ & 4,243 \\
\hline Wants to Learn as Much as Possible & $\begin{array}{l}0.049 * \\
(0.026)\end{array}$ & $\begin{array}{l}0.045 * \\
(0.026)\end{array}$ & $\begin{array}{c}0.042 \\
(0.026)\end{array}$ & 4,245 \\
\hline Strong Desire to Master Course Material & $\begin{array}{c}0.087 * * * \\
(0.021)\end{array}$ & $\begin{array}{c}0.086 * * * \\
(0.021)\end{array}$ & $\begin{array}{c}0.083^{* * *} \\
(0.023)\end{array}$ & 4,245 \\
\hline Confidence in Mastering Course Material & $\begin{array}{c}0.062 * \\
(0.033)\end{array}$ & $\begin{array}{c}0.065 * \\
(0.034)\end{array}$ & $\begin{array}{c}0.078 * * \\
(0.033)\end{array}$ & 4,245 \\
\hline Confidence in Solving the Hardest Problems & $\begin{array}{c}0.071 * * * \\
(0.021)\end{array}$ & $\begin{array}{c}0.076 * * * \\
(0.020)\end{array}$ & $\begin{array}{c}0.067 * * * \\
(0.023)\end{array}$ & 4,245 \\
\hline
\end{tabular}

\begin{tabular}{|c|c|c|c|}
\hline Student and Parent Characteristics & No & Yes & Yes \\
\hline $\begin{array}{l}\text { Education Spending in province per High School Student in } \\
\text { Each High School Cohort }\end{array}$ & No & No & Yes \\
\hline
\end{tabular}

Each High School Cohort

Only the coefficients of New Curriculum are reported. Standard errors, clustered at province×high school cohort level (128 clusters), are reported in parentheses. Province fixed effects, high school cohort fixed effects, college fixed effects and a dummy variable indicating whether the student is a freshman in university are included in all regressions. 
Table 5B

The Effect of the Curriculum Reform on Happiness, BMI and Mental Health

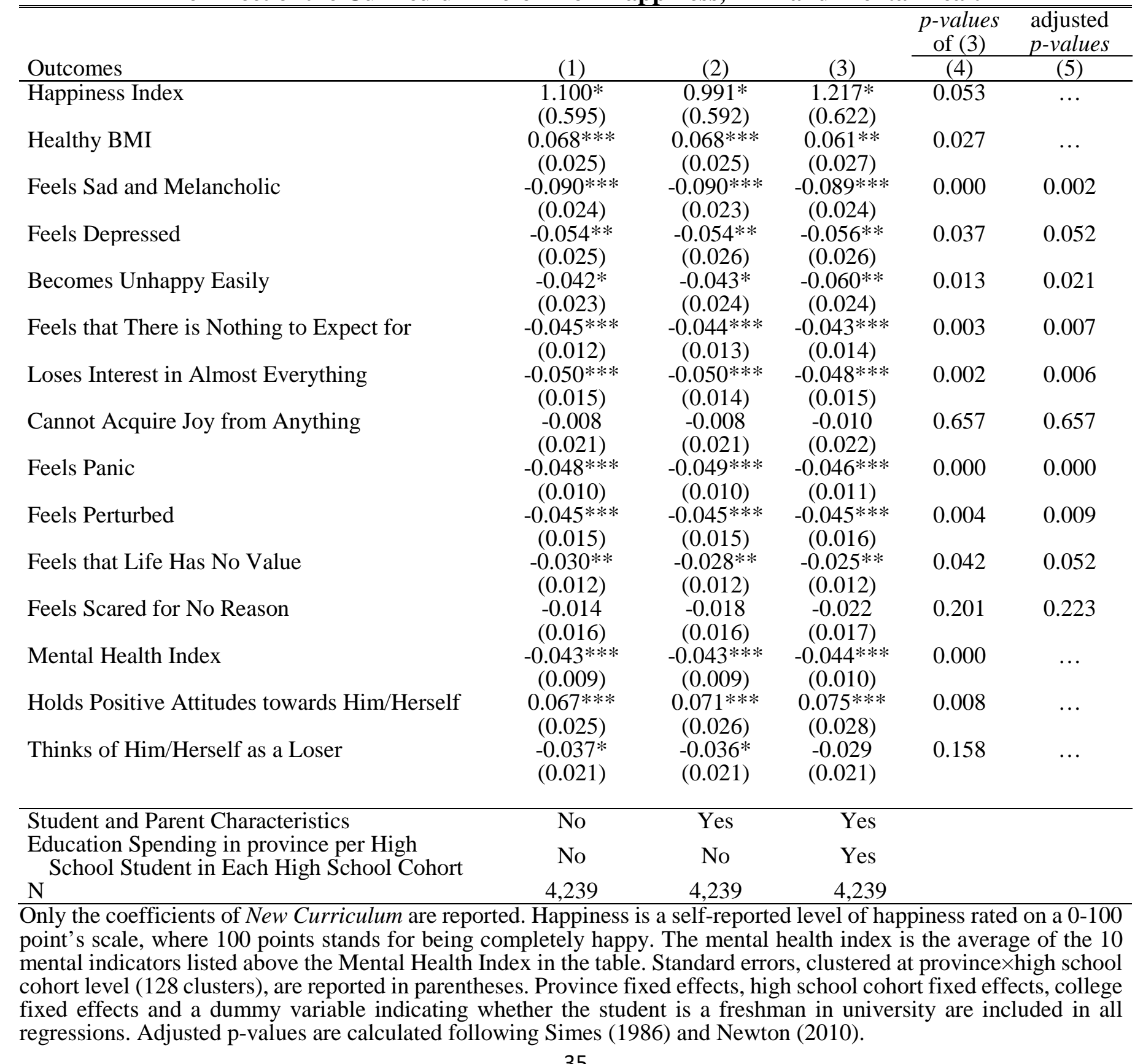


Table 6A

The Effect of the Curriculum Reform on Education Outcomes, Self-Confidence, and Membership in Student Clubs: Sensitivity to the Variations in the Sample

\begin{tabular}{|c|c|c|c|}
\hline Outcomes & $\begin{array}{l}\text { Excluding } \\
\text { Students from } \\
\text { Shanghai } \\
\text { (1) }\end{array}$ & $\begin{array}{l}\text { Excluding } \\
\text { Students Who Did } \\
\text { Not Take College } \\
\text { Entrance Exam } \\
\text { (2) }\end{array}$ & $\begin{array}{l}\text { Excluding Students } \\
\text { Who Took the College } \\
\text { Entrance Exam } \\
\text { Multiple Times } \\
\text { (3) }\end{array}$ \\
\hline Number of "A" Grades & $0.466^{* * *}$ & $0.548 * * *$ & $0.419 * *$ \\
\hline Current Rank in University & $\begin{array}{c}(0.157) \\
-3.767 * * * \\
(0.939)\end{array}$ & $\begin{array}{c}(0.158) \\
-3.553 * * * \\
(0.823)\end{array}$ & $\begin{array}{c}(0.160) \\
-3.588 * * * \\
(1.047)\end{array}$ \\
\hline Often Skipped Classes in Major Courses & $\begin{array}{c}-0.017 \\
(0.020)\end{array}$ & $\begin{array}{l}-0.014 \\
(0.019)\end{array}$ & $\begin{array}{l}-0.009 \\
(0.020)\end{array}$ \\
\hline Number of Clubs Joined & $\begin{array}{c}0.410^{* * *} \\
(0.094)\end{array}$ & $\begin{array}{c}0.367 * * * \\
(0.110)\end{array}$ & $\begin{array}{c}0.355^{* * *} * \\
(0.092)\end{array}$ \\
\hline Wants to Learn as Much as Possible & $\begin{array}{c}0.041 \\
(0.026)\end{array}$ & $\begin{array}{c}0.036 \\
(0.026)\end{array}$ & $\begin{array}{c}0.040 \\
(0.028)\end{array}$ \\
\hline Strong Desire to Master Course Material & $\begin{array}{c}0.083 * * * \\
(0.023)\end{array}$ & $\begin{array}{c}0.068 * * * \\
(0.024)\end{array}$ & $\begin{array}{c}0.067 * * * \\
(0.022)\end{array}$ \\
\hline Confidence in Mastering Course Material & $\begin{array}{c}0.078 * * \\
(0.033)\end{array}$ & $\begin{array}{c}0.084 * * * \\
(0.032)\end{array}$ & $\begin{array}{c}0.059 * \\
(0.032)\end{array}$ \\
\hline Confidence in Solving the Hardest Problems & $\begin{array}{c}0.067 * * * \\
(0.023)\end{array}$ & $\begin{array}{c}0.079 * * * \\
(0.030)\end{array}$ & $\begin{array}{c}0.054^{* *} \\
(0.021)\end{array}$ \\
\hline \multirow{2}{*}{$\begin{array}{l}\text { Student and Parent Characteristics } \\
\text { Education Spending in province per High } \\
\text { School Student in Each High School Cohort }\end{array}$} & Yes & Yes & Yes \\
\hline & Yes & Yes & Yes \\
\hline \multicolumn{4}{|c|}{$\begin{array}{l}\text { Only the coefficients of New Curriculum are reported. Standard errors, clustered at provincexhigh school cohort } \\
\text { level (128 clusters), are reported in parentheses. Province fixed effects, high school cohort fixed effects, college } \\
\text { fixed effects and a dummy variable indicating whether the student is a freshman in university are included in }\end{array}$} \\
\hline
\end{tabular}


Table 6B

The Effect of the Curriculum Reform on Happiness, BMI and Mental Health: Sensitivity to the Variations in the Samples

\begin{tabular}{|c|c|c|c|c|c|c|}
\hline Outcomes & $\begin{array}{l}\text { Excluding } \\
\text { Students from } \\
\text { Shanghai } \\
\text { (1) }\end{array}$ & $\begin{array}{l}\text { Adjusted } \\
p \text {-value } \\
\text { (2) }\end{array}$ & $\begin{array}{c}\text { Excluding } \\
\text { Students Who Did } \\
\text { Not Take College } \\
\text { Entrance Exam } \\
\text { (3) }\end{array}$ & $\begin{array}{c}\text { Adjusted } \\
p \text {-value }\end{array}$ & $\begin{array}{c}\text { Excluding Students } \\
\text { Who Took the } \\
\text { College Entrance } \\
\text { Exam Multiple Times } \\
\text { (5) }\end{array}$ & $\begin{array}{c}\text { Adjusted } \\
p \text {-value }\end{array}$ \\
\hline Happiness Index & $\begin{array}{l}1.196 * \\
(0.624)\end{array}$ & $\ldots$ & $\begin{array}{l}1.104^{*} \\
(0.564)\end{array}$ & $\ldots$ & $\begin{array}{c}1.397 * * * \\
(0.507)\end{array}$ & $\ldots$ \\
\hline Healthy BMI & $\begin{array}{l}0.060 * * \\
(0.027)\end{array}$ & $\ldots$ & $\begin{array}{l}0.046^{*} \\
(0.028)\end{array}$ & $\ldots$ & $\begin{array}{c}0.083^{* * *} * \\
(0.026)\end{array}$ & $\ldots$ \\
\hline Feels Sad and Melancholic & $\begin{array}{c}-0.088 * * * \\
(0.024)\end{array}$ & 0.002 & $\begin{array}{c}-0.102 * * * \\
(0.031)\end{array}$ & 0.007 & $\begin{array}{c}-0.092 * * * \\
(0.023)\end{array}$ & 0.000 \\
\hline Feels Depressed & $\begin{array}{c}-0.055^{* *} \\
(0.026)\end{array}$ & 0.054 & $\begin{array}{l}-0.054^{*} \\
(0.033)\end{array}$ & 0.140 & $\begin{array}{c}-0.052^{* * *} \\
(0.025)\end{array}$ & 0.056 \\
\hline Becomes Unhappy Easily & $\begin{array}{c}-0.060 * * \\
(0.024)\end{array}$ & 0.020 & $\begin{array}{c}-0.061^{* *} \\
(0.028)\end{array}$ & 0.053 & $\begin{array}{c}-0.034^{* *} \\
(0.015)\end{array}$ & 0.044 \\
\hline Feels that There is Nothing to Expect for & $\begin{array}{c}-0.042 * * * \\
(0.014)\end{array}$ & 0.008 & $\begin{array}{c}-0.043 * * * \\
(0.015)\end{array}$ & 0.015 & $\begin{array}{c}-0.052^{* * * *} \\
(0.011)\end{array}$ & 0.000 \\
\hline Loses Interest in Almost Everything & $\begin{array}{c}-0.048 * * * \\
(0.015)\end{array}$ & 0.006 & $\begin{array}{c}-0.048 * * * \\
(0.015)\end{array}$ & 0.008 & $\begin{array}{c}-0.050 * * * \\
(0.008)\end{array}$ & 0.000 \\
\hline Cannot Acquire Joy from Anything & $\begin{array}{l}-0.009 \\
(0.022)\end{array}$ & 0.678 & $\begin{array}{c}-0.013 \\
(0.024)\end{array}$ & 0.581 & $\begin{array}{c}0.005 \\
(0.017)\end{array}$ & 0.777 \\
\hline Feels Panic & $\begin{array}{c}-0.046 * * * \\
(0.010)\end{array}$ & 0.000 & $\begin{array}{c}-0.047 * * * \\
(0.010)\end{array}$ & 0.000 & $\begin{array}{c}-0.040 * * * \\
(0.009)\end{array}$ & 0.000 \\
\hline Feels Perturbed & $\begin{array}{c}-0.045 * * * \\
(0.016)\end{array}$ & 0.009 & $\begin{array}{c}-0.036^{* *} \\
(0.016)\end{array}$ & 0.053 & $\begin{array}{c}-0.050 * * * \\
(0.013)\end{array}$ & 0.001 \\
\hline Feels that Life Has No Value & $\begin{array}{c}-0.025^{* *} \\
(0.012)\end{array}$ & 0.054 & $\begin{array}{l}-0.019 \\
(0.012)\end{array}$ & 0.148 & $\begin{array}{l}-0.022^{*} \\
(0.011)\end{array}$ & 0.070 \\
\hline Feels Scared for No Reason & $\begin{array}{l}-0.022 \\
(0.017)\end{array}$ & 0.222 & $\begin{array}{c}-0.019 \\
(0.017)\end{array}$ & 0.291 & $\begin{array}{l}-0.021 \\
(0.018)\end{array}$ & 0.287 \\
\hline Mental Health Index & $\begin{array}{c}-0.044 * * * \\
(0.010)\end{array}$ & $\ldots$ & $\begin{array}{c}-0.044 * * * \\
(0.011)\end{array}$ & $\ldots$ & $\begin{array}{c}-0.041^{* * * *} \\
(0.006)\end{array}$ & $\ldots$ \\
\hline Holds Positive Attitudes towards Him/Herself & $\begin{array}{c}0.074^{* * * *} \\
(0.028)\end{array}$ & $\ldots$ & $\begin{array}{c}0.085 * * * \\
(0.024)\end{array}$ & $\ldots$ & $\begin{array}{c}0.084^{* * *} \\
(0.027)\end{array}$ & $\ldots$ \\
\hline Thinks of Him/Herself as a Loser & $\begin{array}{l}-0.030 \\
(0.021)\end{array}$ & ... & $\begin{array}{c}-0.034 \\
(0.021)\end{array}$ & $\ldots$ & $\begin{array}{l}-0.017 \\
(0.015)\end{array}$ & ... \\
\hline Student and Parent Characteristics & Yes & & Yes & & Yes & \\
\hline $\begin{array}{l}\text { Education Spending in province per High } \\
\text { School Student in Each High School Cohort }\end{array}$ & Yes & & Yes & & Yes & \\
\hline $\mathrm{N}$ & 4,176 & & 4,021 & & 3,600 & \\
\hline
\end{tabular}


Table 7A

The Effect of the Curriculum Reform on Education Outcomes, Self-Confidence, and Membership in Student Clubs: Sensitivity to the Variations in Model Specification

\begin{tabular}{|c|c|c|c|c|}
\hline Outcomes & $(1)$ & $(2)$ & $(3)$ & \# of Obs. \\
\hline \multirow[t]{2}{*}{ Number of “A” Grades } & $0.470 * * *$ & $0.355 * *$ & $0.460 * * *$ & $(4)$ \\
\hline & $(0.156)$ & $(0.162)$ & $(0.156)$ & 4,195 \\
\hline \multirow[t]{2}{*}{ Current Rank in University } & $-3.785 * * *$ & $-4.278 * * *$ & $-3.927 * * *$ & \\
\hline & $(0.940)$ & $(0.890)$ & $(0.909)$ & 4,122 \\
\hline \multirow[t]{2}{*}{ Often Skipped Classes in Major Courses } & -0.017 & -0.006 & -0.014 & \\
\hline & $(0.020)$ & $(0.022)$ & $(0.021)$ & 3,953 \\
\hline \multirow[t]{2}{*}{ Number of Clubs Joined } & $0.411^{* * *}$ & $0.451 * * *$ & $0.438 * * *$ & \\
\hline & $(0.094)$ & $(0.112)$ & $(0.099)$ & 4,243 \\
\hline \multirow[t]{2}{*}{ Wants to Learn as Much as Possible } & 0.042 & $0.048 * *$ & $0.041^{*}$ & \\
\hline & $(0.026)$ & $(0.024)$ & $(0.025)$ & 4,245 \\
\hline \multirow[t]{2}{*}{ Strong Desire to Master Course Material } & $0.083^{* * *}$ & $0.086 * * *$ & $0.082 * * *$ & \\
\hline & $(0.023)$ & $(0.024)$ & $(0.024)$ & 4,245 \\
\hline \multirow[t]{2}{*}{ Confidence in Mastering Course Material } & $0.078 * *$ & 0.056 & $0.067 * *$ & \\
\hline & $(0.033)$ & $(0.036)$ & $(0.034)$ & 4,245 \\
\hline \multirow[t]{2}{*}{ Confidence in Solving the Hardest Problems } & $0.067 * * *$ & 0.031 & $0.058 * *$ & \\
\hline & $(0.023)$ & $(0.026)$ & $(0.023)$ & 4,245 \\
\hline \multirow{2}{*}{$\begin{array}{l}\text { Student and Parent Characteristics } \\
\text { Education Spending in province per High School } \\
\text { Student in Each High School Cohort }\end{array}$} & Yes & Yes & Yes & \\
\hline & Yes & Yes & Yes & \\
\hline Provincial Time-Varying Controls & No & Yes & No & \\
\hline $\mathrm{GRP}_{2003} \times$ Cohort Fixed Effects & No & No & Yes & \\
\hline
\end{tabular}


Table 7B

The Effect of the Curriculum Reform on Happiness, BMI and Mental Health: Sensitivity to the Variations in Model Specification

\begin{tabular}{|c|c|c|c|}
\hline Outcomes & (1) & $\overline{(2)}$ & (3) \\
\hline Happiness Index & $\begin{array}{l}1.217^{*} \\
(0.622)\end{array}$ & $\begin{array}{c}0.978 \\
(0.690)\end{array}$ & 1.132* \\
\hline Healthy BMI & $\begin{array}{c}0.061^{* *} \\
(0.027)\end{array}$ & $\begin{array}{c}0.061 * * \\
(0.030)\end{array}$ & $\begin{array}{l}0.056^{*} \\
(0.029)\end{array}$ \\
\hline Feels Sad and Melancholic & $\begin{array}{c}-0.089 * * * \\
(0.024)\end{array}$ & $\begin{array}{c}-0.078 * * * \\
(0.026)\end{array}$ & $\begin{array}{c}-0.094 * * * \\
(0.024)\end{array}$ \\
\hline Feels Depressed & $\begin{array}{c}-0.056^{* *} \\
(0.026)\end{array}$ & $\begin{array}{c}-0.073^{* *} \\
(0.028)\end{array}$ & $\begin{array}{c}-0.069 * * * \\
(0.026)\end{array}$ \\
\hline Becomes Unhappy Easily & $\begin{array}{c}-0.060 * * \\
(0.024)\end{array}$ & $\begin{array}{l}-0.046 \\
(0.032)\end{array}$ & $\begin{array}{c}-0.061^{* *} \\
(0.026)\end{array}$ \\
\hline Feels that There is Nothing to Expect for & $\begin{array}{c}-0.043^{* * *} * \\
(0.014)\end{array}$ & $\begin{array}{c}-0.049 * * * \\
(0.018)\end{array}$ & $\begin{array}{c}-0.047 * * * \\
(0.015)\end{array}$ \\
\hline Loses Interest in Almost Everything & $\begin{array}{c}-0.048 * * * \\
(0.015)\end{array}$ & $\begin{array}{c}-0.053 * * * \\
(0.016)\end{array}$ & $\begin{array}{c}-0.054 * * * \\
(0.016)\end{array}$ \\
\hline Cannot Acquire Joy from Anything & $\begin{array}{c}-0.01 \\
(0.022)\end{array}$ & $\begin{array}{l}-0.012 \\
(0.026)\end{array}$ & $\begin{array}{l}-0.011 \\
(0.023)\end{array}$ \\
\hline Feels Panic & $\begin{array}{c}-0.046^{* * *} \\
(0.011)\end{array}$ & $\begin{array}{c}-0.049 * * * \\
(0.014)\end{array}$ & $\begin{array}{c}-0.045^{* * *} \\
(0.012)\end{array}$ \\
\hline Feels Perturbed & $\begin{array}{c}-0.045^{* * *} * \\
(0.016)\end{array}$ & $\begin{array}{c}-0.038 * * \\
(0.018)\end{array}$ & $\begin{array}{c}-0.042^{* *} \\
(0.016)\end{array}$ \\
\hline Feels that Life Has No Value & $\begin{array}{c}-0.025^{* *} \\
(0.012)\end{array}$ & $\begin{array}{l}-0.014 \\
(0.013)\end{array}$ & $\begin{array}{c}-0.019 \\
(0.012)\end{array}$ \\
\hline Feels Scared for No Reason & $\begin{array}{l}-0.022 \\
(0.017)\end{array}$ & $\begin{array}{l}-0.019 \\
(0.019)\end{array}$ & $\begin{array}{l}-0.022 \\
(0.017)\end{array}$ \\
\hline Mental Health Index & $\begin{array}{c}-0.044 * * * \\
(0.010)\end{array}$ & $\begin{array}{c}-0.043 * * * \\
(0.012)\end{array}$ & $\begin{array}{c}-0.046 * * * \\
(0.011)\end{array}$ \\
\hline Holds Positive Attitudes towards Him/Herself & $\begin{array}{c}0.075^{* * *} \\
(0.028)\end{array}$ & $\begin{array}{l}0.052^{*} \\
(0.028)\end{array}$ & $\begin{array}{c}0.064^{* *} \\
(0.029)\end{array}$ \\
\hline Thinks of Him/Herself as a Loser & $\begin{array}{l}-0.029 \\
(0.021)\end{array}$ & $\begin{array}{l}-0.007 \\
(0.021)\end{array}$ & $\begin{array}{l}-0.021 \\
(0.021)\end{array}$ \\
\hline Student and Parent Characteristics & Yes & Yes & Yes \\
\hline $\begin{array}{l}\text { Education Spending in province per High School } \\
\text { Student in Each High School Cohort }\end{array}$ & Yes & Yes & Yes \\
\hline Provincial Time-Varying Controls & No & Yes & No \\
\hline $\mathrm{GRP}_{2003} \times$ Cohort Fixed Effects & No & No & Yes \\
\hline $\mathrm{N}$ & 4,239 & 4,239 & 4,239 \\
\hline
\end{tabular}

Only the coefficients of New Curriculum are reported. Standard errors, clustered at province $\times$ high school cohort level (128 clusters), are reported in parentheses. Province fixed effects, high school cohort fixed effects, college fixed effects and a dummy variable indicating whether the student is a freshman in university are included in all regressions. 


\begin{tabular}{|c|c|c|}
\hline \multicolumn{3}{|c|}{$\begin{array}{l}\text { Appendix Table A1 } \\
\text { The Effect of the Curriculum Reform on Other (Mental) Health Indicators }\end{array}$} \\
\hline "Variables & Details & $\begin{array}{c}\text { New } \\
\text { Curriculum }\end{array}$ \\
\hline $\begin{array}{l}\text { Won’t Be Happy } \\
\text { Again }\end{array}$ & $\begin{array}{l}\text { Dummy variable if the student finds the statement of "I feel that I will } \\
\text { not be } 9 \text { happy again" often or completely applies to him/her. }\end{array}$ & $\begin{array}{c}-0.048^{* *} \\
(0.019)\end{array}$ \\
\hline Feels Trembled & $\begin{array}{l}\text { Dummy variable if the student finds the statement of "I feel trembled" } \\
\text { often or completely applies to him/her. }\end{array}$ & $\begin{array}{c}-0.037 * * \\
(0.017)\end{array}$ \\
\hline Feels Hard to Relax & $\begin{array}{l}\text { Dummy variable if the student finds the statement of "I feel hard to } \\
\text { make myself relaxed" often or completely applies to him/her. }\end{array}$ & $\begin{array}{l}0.022 \\
(0.027)\end{array}$ \\
\hline Feels Exhausted & $\begin{array}{l}\text { Dummy variable if the student finds the statement of "I feel exhausted" } \\
\text { often or completely applies to him/her. }\end{array}$ & $\begin{array}{l}-0.074 * * * \\
(0.027)\end{array}$ \\
\hline $\begin{array}{l}\text { Easy to Become } \\
\text { Angry }\end{array}$ & $\begin{array}{l}\text { Dummy variable if the student finds the statement of "I think I am easy } \\
\text { to become angry" often or completely applies to him/her. }\end{array}$ & -0.018 \\
\hline Feels Restless & $\begin{array}{l}\text { Dummy variable if the student finds the statement of "I feel restless" } \\
\text { often or completely applies to him/her. }\end{array}$ & $\begin{array}{c}-0.068 * * \\
(0.034)\end{array}$ \\
\hline Feels Nervous & $\begin{array}{l}\text { Dummy variable if the student finds the statement of "I feel nervous" } \\
\text { often or completely applies to him/her. }\end{array}$ & $\begin{array}{l}-0.014 \\
(0.022)\end{array}$ \\
\hline No Hope in Future & $\begin{array}{l}\text { Dummy variable if the student finds the statement of "I feel that there is } \\
\text { no hope in the future" often or completely applies to him/her. }\end{array}$ & $\begin{array}{c}0.003 \\
(0.014)\end{array}$ \\
\hline $\mathrm{N}$ & & 4,244 \\
\hline
\end{tabular}


Appendix Table A2

Test for Selection on Observable Individual Characteristics

\begin{tabular}{|c|c|c|c|c|c|c|c|}
\hline $\begin{array}{c}\text { Dependent } \\
\text { Variables }\end{array}$ & $\begin{array}{l}\text { Number of } \\
\text { "A" Grades }\end{array}$ & $\begin{array}{l}\text { Current Rank } \\
\text { in University }\end{array}$ & $\begin{array}{l}\text { Often Skipped } \\
\text { Classes in } \\
\text { Major Courses }\end{array}$ & $\begin{array}{c}\text { Number of } \\
\text { Clubs Joined }\end{array}$ & $\begin{array}{c}\text { Wants to Learn } \\
\text { as Much as } \\
\text { Possible }\end{array}$ & $\begin{array}{c}\text { Strong Desire } \\
\text { to Master } \\
\text { Course } \\
\text { Material } \\
\end{array}$ & $\begin{array}{c}\text { Confidence in } \\
\text { Mastering } \\
\text { Course } \\
\text { Material } \\
\end{array}$ \\
\hline New Curriculum & $\begin{array}{l}-0.027 \\
(0.073)\end{array}$ & $\begin{array}{l}-0.006 \\
(0.182)\end{array}$ & $\begin{array}{l}-0.003 \\
(0.002)\end{array}$ & $\begin{array}{c}0.002 \\
(0.031)\end{array}$ & $\begin{array}{c}0.001 \\
(0.006)\end{array}$ & $\begin{array}{c}0.004 \\
(0.003)\end{array}$ & $\begin{array}{l}-0.004 \\
(0.005)\end{array}$ \\
\hline $\begin{array}{c}\mathrm{N} \\
\text { Mean of DV }\end{array}$ & $\begin{array}{c}4,195 \\
3.19\end{array}$ & $\begin{array}{l}4,122 \\
14.78\end{array}$ & $\begin{array}{c}3,953 \\
0.07\end{array}$ & $\begin{array}{c}4,243 \\
2.51\end{array}$ & $\begin{array}{c}4,245 \\
0.70\end{array}$ & $\begin{array}{c}4,245 \\
0.57\end{array}$ & $\begin{array}{c}4,245 \\
0.31\end{array}$ \\
\hline $\begin{array}{c}\text { Dependent } \\
\text { Variables }\end{array}$ & $\begin{array}{l}\text { Confidence } \\
\text { in Solving } \\
\text { the Hardest } \\
\text { Problems }\end{array}$ & $\begin{array}{c}\text { Level of } \\
\text { Satisfaction } \\
\text { with China’s } \\
\text { Current } \\
\text { Development }\end{array}$ & $\begin{array}{c}\text { Level of } \\
\text { Optimism } \\
\text { about China’s } \\
\text { Future } \\
\text { Development }\end{array}$ & $\begin{array}{l}\text { Happiness } \\
\text { Index }\end{array}$ & Healthy BMI & $\begin{array}{c}\text { Mental Health } \\
\text { Index }\end{array}$ & \\
\hline New Curriculum & $\begin{array}{c}-0.008 * \\
(0.004)\end{array}$ & $\begin{array}{l}-0.044 \\
(0.089)\end{array}$ & $\begin{array}{l}-0.048 \\
(0.086)\end{array}$ & $\begin{array}{l}-0.007 \\
(0.149)\end{array}$ & $\begin{array}{c}0.006 \\
(0.004)\end{array}$ & $\begin{array}{c}0.001 \\
(0.001)\end{array}$ & \\
\hline $\begin{array}{c}\mathrm{N} \\
\text { Mean of DV }\end{array}$ & $\begin{array}{c}4,245 \\
0.56\end{array}$ & $\begin{array}{l}4,246 \\
77.30\end{array}$ & $\begin{array}{l}4,246 \\
81.43\end{array}$ & $\begin{array}{l}4,239 \\
83.85\end{array}$ & $\begin{array}{c}4,239 \\
0.70\end{array}$ & $\begin{array}{c}4,239 \\
0.12\end{array}$ & \\
\hline
\end{tabular}

The dependent variables in this table are predicted outcomes based on students' individual characteristics, university fixed effects, high school cohort fixed effects, and province fixed effects. A full set of cohort fixed effects and province effects are included in all regressions. The standard errors are in parentheses, which are clustered at province×high school cohort level (128 clusters). 


\section{Appendix Table A3}

The Effect of the Curriculum Reform on Students' Satisfaction with China's Current and Future Economic Development

Dependent Variable

Level of Satisfaction with China's Current

Development
Level of Optimism about China's Future

$(1)$

Development

(2) (3)

$1.995^{* * *}$ (4)

(0.730)

$(0.707)$

$1.972^{* * *}$

(5)

$3.119 * * *$

(0.593)

(0.642)

$2.946 * * *$

$1.696 * *$

(6)

(6)

(7)

(8)

(0.626)

$(0.593)$

4,246

(0.630)

$2.937^{* * *}$

(0.746)

2.956**

(0.731)

$2.812^{* * *}$

N

4,24

Student and Parent Characteristics

Education Spending in province per High

School Student in Each High School Cohort

Excluding Students from Shanghai

Excluding Students Who Did Not Take College Entrance Exam

Excluding Students Who Took the College

Entrance Exam Multiple Times

Provincial Time-Varying Controls $\mathrm{GRP}_{2003} \times$ Cohort Fixed Effects

\begin{tabular}{ccccccccc}
4,246 & 4,246 & 4,246 & 4,183 & 4,028 & 3,606 & 4,626 & 4,626 \\
$\times$ & $\sqrt{ }$ & $\sqrt{ }$ & $\sqrt{ }$ & $\sqrt{ }$ & $\sqrt{ }$ & $\sqrt{ }$ & $\sqrt{ }$ \\
$\times$ & $\times$ & $\sqrt{ }$ & $\sqrt{ }$ & $\sqrt{ }$ & $\sqrt{ }$ & $\sqrt{ }$ & $\sqrt{ }$ \\
$\times$ & $\times$ & $\times$ & $\sqrt{ }$ & $\times$ & $\times$ & $\times$ & $\times$ \\
$\times$ & $\times$ & $\times$ & $\times$ & $\sqrt{ }$ & $\times$ & $\times$ & $\times$ \\
$\times$ & $\times$ & $\times$ & $\times$ & $\times$ & $\sqrt{ }$ & $\times$ & $\times$ \\
$\times$ & $\times$ & $\times$ & $\times$ & $\times$ & $\times$ & $\sqrt{ }$ & $\times$ \\
$\times$ & $\times$ & $\times$ & $\times$ & $\times$ & $\times$ & $\times$ & $\sqrt{ }$ \\
\hline
\end{tabular}

In the working sample of 4,246 observations, the mean of the dependent variables are 77.30 and 81.30 , respectively; the standard errors of the dependent variables are 11.83 and 12.06 , respectively. 
Figure 1

The Distribution of the Coefficient of New Curriculum: Dropping from the Sample One Province at a Time

Number of A Grades

Often Skipped Classes in Major Courses

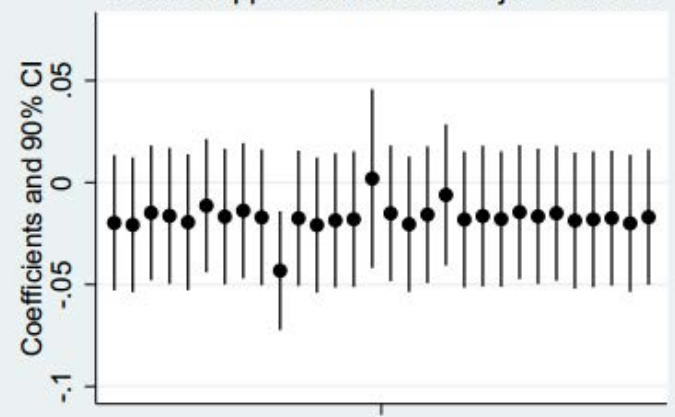

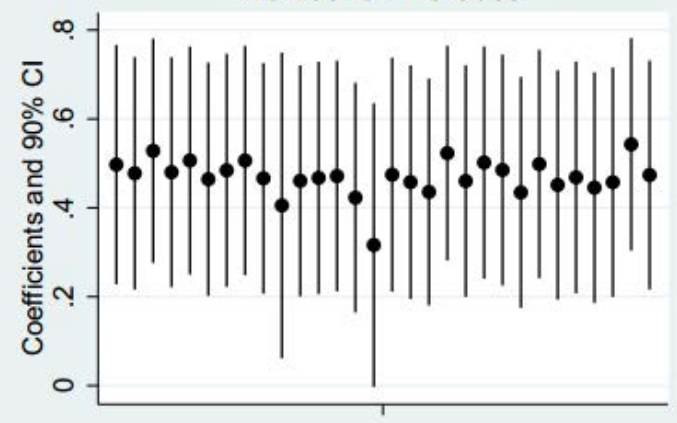

Current Rank in University

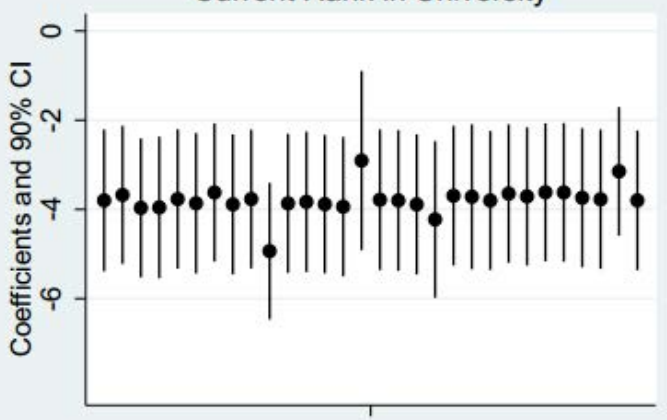

Number of Clubs Joined

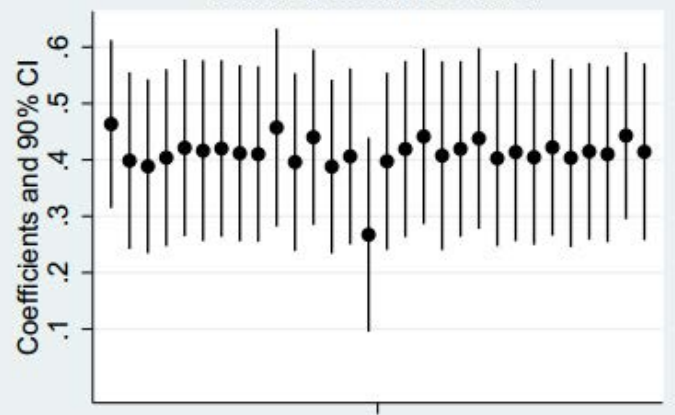

Desire to Master Course Material

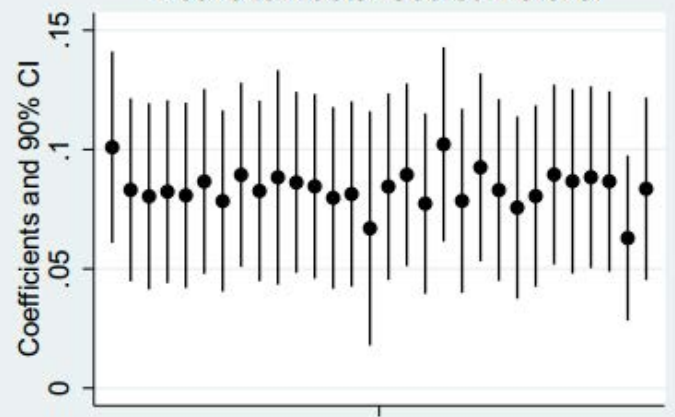

Confidence in Solving the Hardest Problems
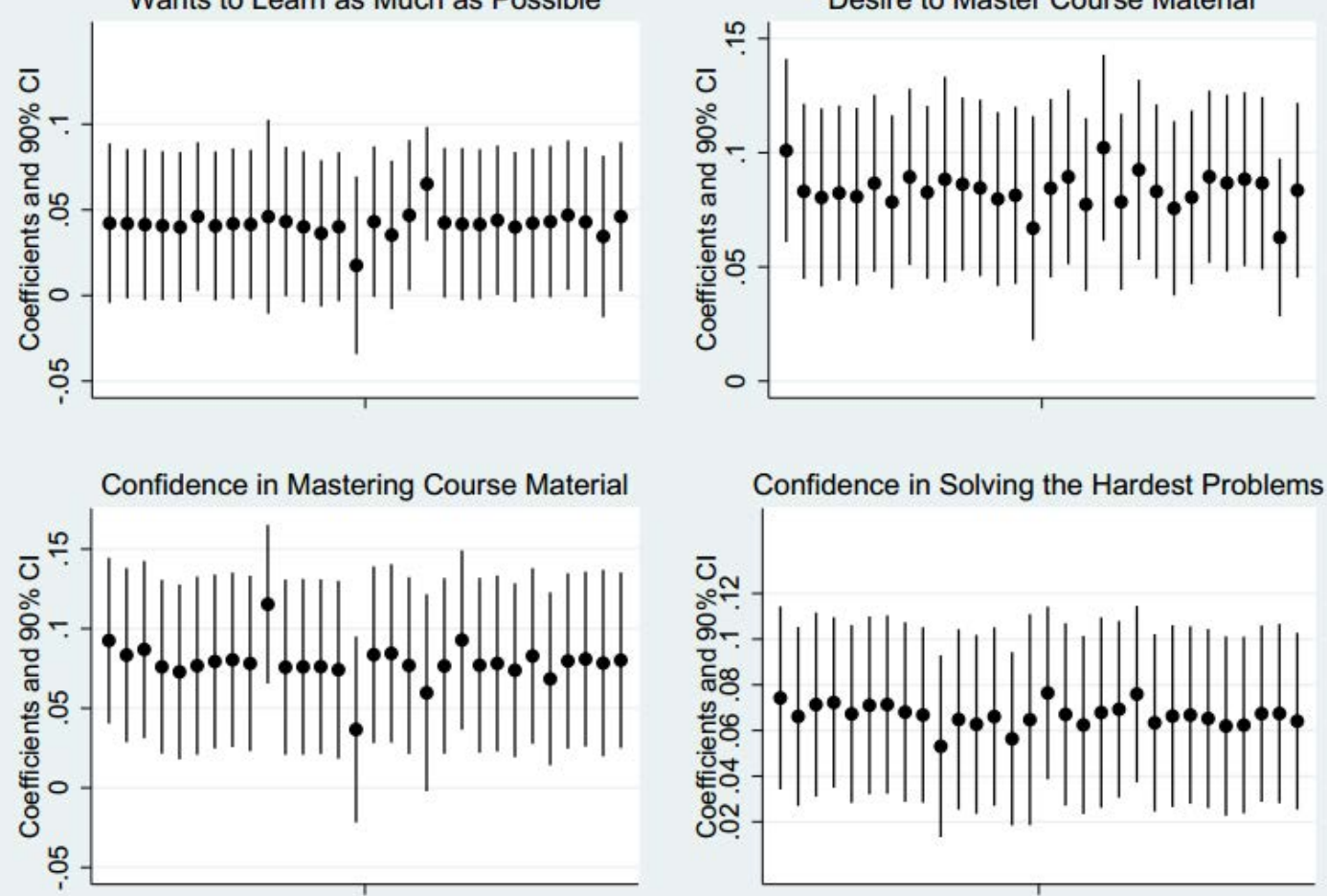

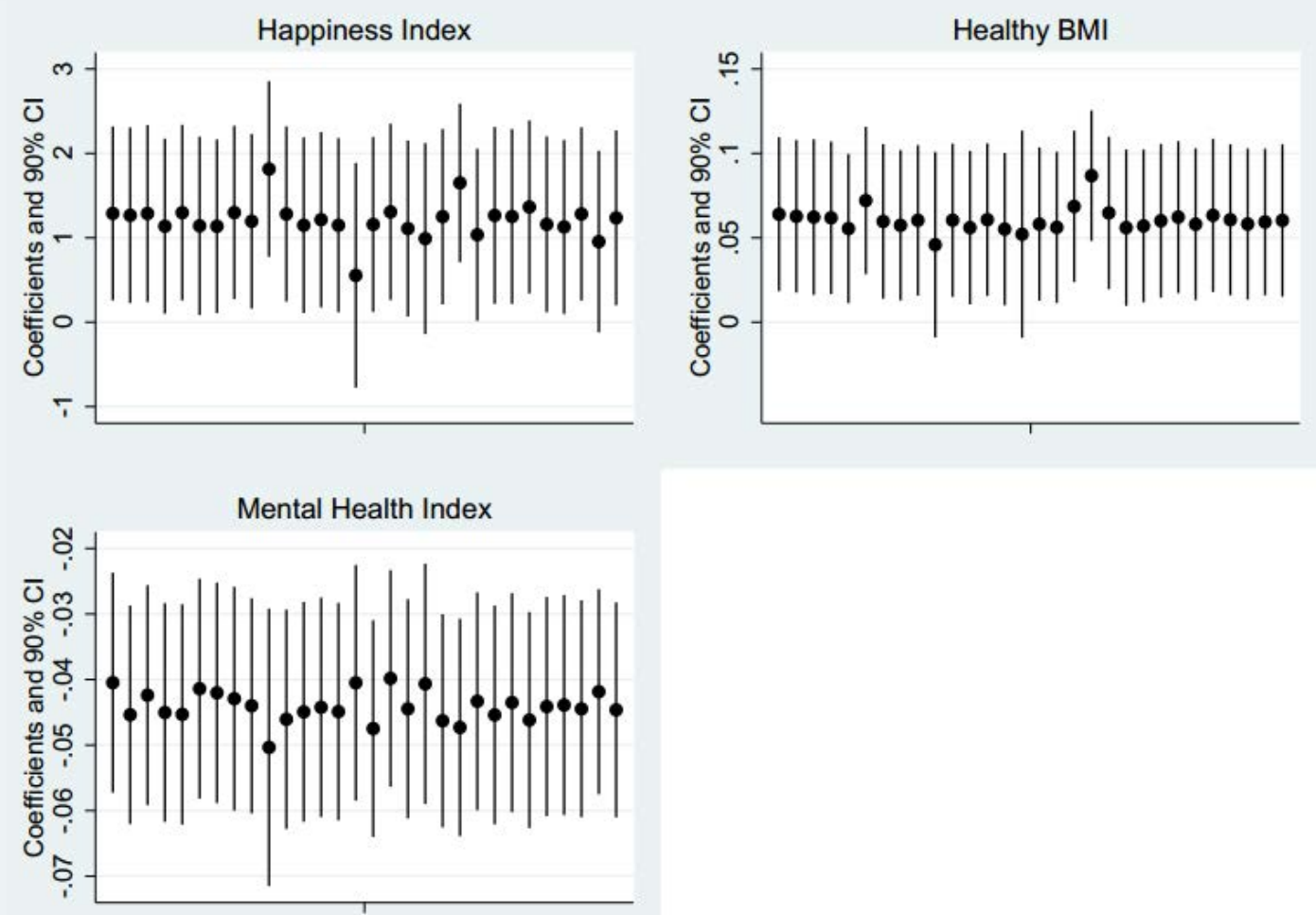
Figure 2

Distribution of the t-Statistics of the Treatment Coefficients

Based on Random Assignment of the Reform Implementation Years
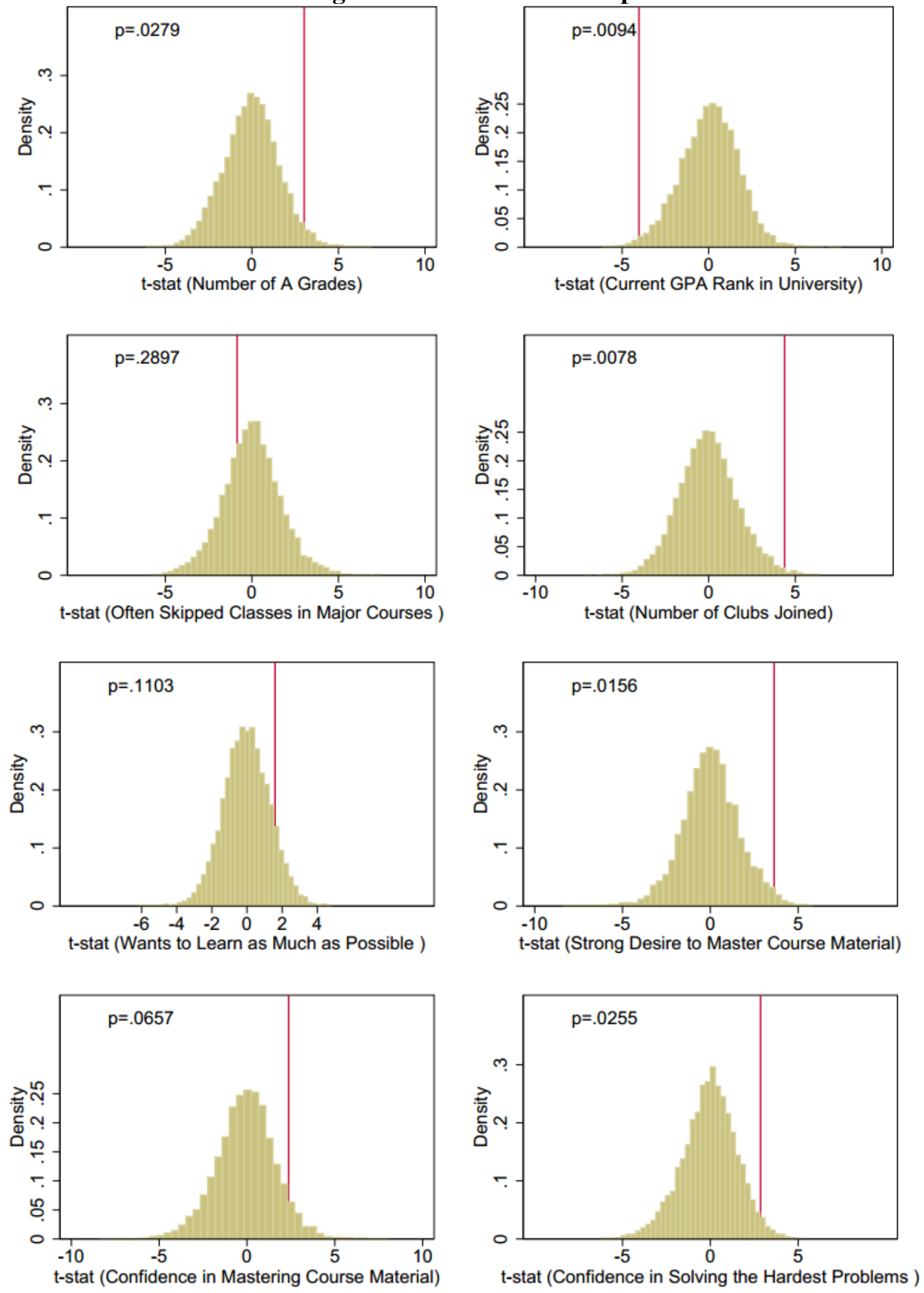

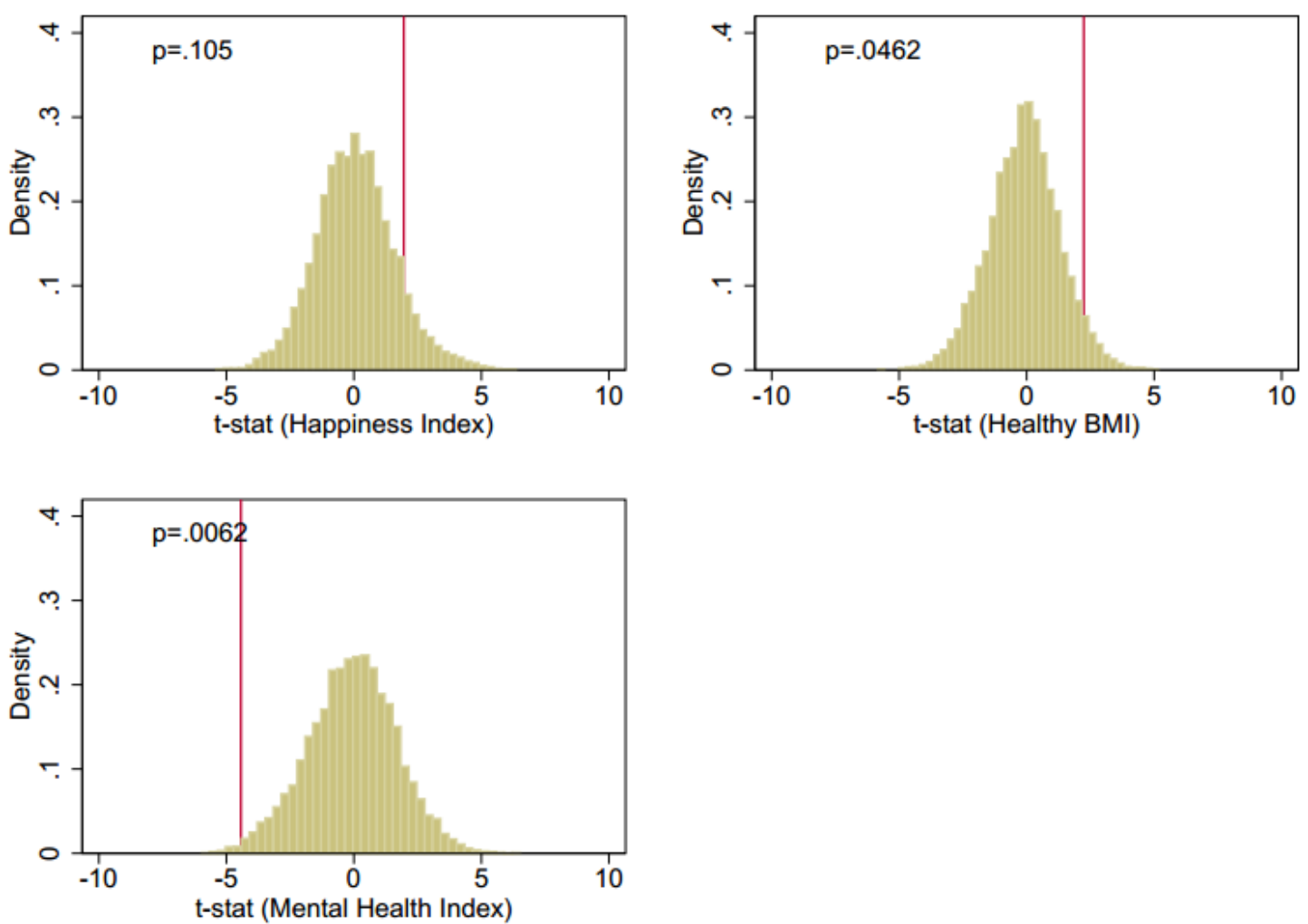